\title{
Impacts of drainage, restoration and warming on boreal wetland greenhouse gas fluxes
}

\section{Laine, A. M.}

2019-01-10

Laine , A M , Mehtätalo , L , Tolvanen , A , Frolking , S \& Tuittila , E-S 2019 , ' Impacts of drainage, restoration and warming on boreal wetland greenhouse gas fluxes ', The Science of the Total Environment, vol. 647 , pp. 169-181 . https://doi.org/10.1016/j.scitotenv.2018.07.390

http://hdl.handle.net/10138/318101

https://doi.org/10.1016/j.scitotenv.2018.07.390

cc_by_nc_nd

acceptedVersion

Downloaded from Helda, University of Helsinki institutional repository.

This is an electronic reprint of the original article.

This reprint may differ from the original in pagination and typographic detail.

Please cite the original version. 
1 Impacts of drainage, restoration and warming on boreal wetland greenhouse gas

2 fluxes

3 Laine, A.M. ${ }^{1,2,3 *}$, Mehtätalo, L. ${ }^{4}$, Tolvanen, A. ${ }^{2,5}$ Frolking, S $^{3,6}$, Tuittila, E.-S. ${ }^{3}$

$4 \quad{ }^{1}$ Department of Forest Science, University of Helsinki, P.O. Box 27, FI-00014 University of 5 Helsinki, Finland;

$6 \quad{ }^{2}$ Department of Ecology and Genetics, University of Oulu, P.O. Box 3000, FI-90014

7 University of Oulu. Fax +35885531061

$8 \quad{ }^{3}$ School of Forest Sciences, University of Eastern Finland, P.O. Box 111, FI-80101 Joensuu,

$9 \quad$ Finland; eeva-stiina.tuittila@uef.fi

$10{ }^{4}$ School of Computing, University of Eastern Finland, P.O. Box 111, FI-80101 Joensuu,

11 Finland; lauri.mehtatalo@uef.fi

$12{ }^{5}$ Natural Resources Institute Finland (Luke), P.O. Box 413, FI-90014 University of Oulu,

13 Finland; anne.tolvanen@luke.fi

$14{ }^{6}$ Institute for the Study of Earth, Oceans, and Space, University of New Hampshire, 8 College

15 Road, Durham, NH 03824-3525, USA; steve.frolking@unh.edu

$16{ }^{*}$ Corresponding author: Current address, School of Forest Sciences, University of Eastern

17 Finland, P.O. Box 111, FI-80101 Joensuu, Finland; anna.laine@oulu.fi

19 To be submitted to Science of the total environment as a Primary Research Article

20 Running head: land use and warming impacts gas fluxes 


\section{Abstract}

22 Northern wetlands with organic soil i.e., mires are significant carbon storages. This key

23 ecosystem service may be threatened by anthropogenic activities and climate change, yet we

24 still lack a consensus on how these major changes affects their carbon sink capacities. We

25 studied how forestry drainage and restoration combined with experimental warming, impacts

26 greenhouse gas fluxes of wetlands with peat. We measured $\mathrm{CO}_{2}$ and $\mathrm{CH}_{4}$ during two and $\mathrm{N}_{2} \mathrm{O}$

27 fluxes during one growing season using the chamber method.

28 Gas fluxes were primarily controlled by water table, leaf area and temperature. Land use had

29 a clear impact of on $\mathrm{CO}_{2}$ exchange. Forestry drainage increased respiration rates and

30 decreased field layer net ecosystem $\mathrm{CO}_{2}$ uptake (NEE) and leaf area index (LAI), while at

31 restoration sites the flux rates and LAI had recovered to the level of undrained sites. $\mathrm{CH}_{4}$

32 emissions were exceptionally low at all sites during our study years due to natural drought,

33 but still somewhat lower at drained compared to undrained sites. Moderate warming triggered

34 an increase in LAI across all land use types. This was accompanied by an increase in

35 cumulative seasonal NEE. Restoration appeared to be an effective tool to return the

36 ecosystem functions of these wetlands as we found no differences in LAI or any gas flux

37 components (PMAX, Reco, NEE, $\mathrm{CH}_{4}$ or $\mathrm{N}_{2} \mathrm{O}$ ) between restored and undrained sites. We did

38 not find any signs that moderate warming would compromise the return of the ecosystem

39 functions related to $\mathrm{C}$ sequestration.

41 Keywords: forestry drainage, greenhouse gas, land use, peatland, restoration, open top

42 chamber 
Northern wetlands with organic soil i.e., mires have accumulated a large quantity of peat, accounting for some $30 \%$ of global soil carbon (e.g. Yu, 2012). In general, mires have had a small net cooling effect on climate over the Holocene (Frolking, Roulet 2007). Although most undisturbed mires currently act as $\mathrm{CO}_{2}$ sinks (e.g. Lund et al. 2010) and $\mathrm{CH}_{4}$ sources (e.g. Lai 2009) to the atmosphere, it is highly uncertain whether mires have a positive or negative feedback in response to global change (Meng et al. 2016). Moreover, this ecosystem function (i.e., carbon sequestration) that mires provide is sensitive to climate variability (Turetsky et al. 2008) and land use change (Ojanen et al., 2013; Renou-Wilson et al. 2014). Utilization of mires for food or timber production usually requires drainage, as the shallow aerobic surface layer of undrained mires is inadequate to support profitable timber or crop growth (Paavilainen, Päivänen 1995). Altogether 30 Mha of non-tropical and 20 Mha of tropical mires have been disturbed by human activities (Joosten 2010), and of this, approximately half has been drained for forestry (Paavilainen, Päivänen 1995; Miettinen et al. 2016). Forestry drainage causes a regime shift from open mires towards forests as it alters the hydrology, increases the aeration of peat and redirects the vegetation succession towards forest species (Laine et al. 1995; Vompersky, Sirin 1997; Mälson et al. 2008). Drainage increases decomposition and therefore $\mathrm{CO}_{2}$ efflux, while $\mathrm{CH}_{4}$ emissions usually decrease. In most cases, the increased respiration rates are not exceeded by increased productivity and therefore drained mires functions as $\mathrm{C}$ sources and have a climate warming impact (Maljanen et al. 2010; Ojanen et al. 2013; Renou-Wilson et al. 2014; Jauhiainen et al. 2016). There are indicators that some nutrient poor forestry drained mires may continue to act as carbon sinks, 66 however (e.g. Lohila et al. 2011; Ojanen et al. 2013; Hommeltenberg et al. 2014; Ojanen et 67 al. unpublished data). In addition to $\mathrm{CO}_{2}$ and $\mathrm{CH}_{4}$, nitrous oxide is a strong potent GHG. Generally, $\mathrm{N}_{2} \mathrm{O}$ emissions from pristine mires are low and insignificant, but may increase 
significantly after drainage, especially with more nutrient rich conditions (Regina et al. 1996; Ojanen et al. 2010; Pearson et al. 2015).

Ecological restoration aims to assist the recovery of an ecosystem that has been degraded, damaged, or destroyed (Hobbs, Cramer 2008) and recent global and national policies (EU Biodiversity Strategy to 2020; Aichi Biodiversity Targets 2011) regard restoration as a crucial means to safeguard biodiversity. Mire restoration has also been promoted as a key climate mitigation tool (e.g. Bonn et al., 2014), and as a means to decrease a country's greenhouse gas (GHG) emissions (IPCC, 2013). At the same time, carbon markets have been identified as possible funding sources for mire restoration schemes (Bonn et al. 2014). However, data on GHG fluxes from restored mires, especially from those restored after drainage for forestry, are very limited.

The principal restoration methods for forestry drained boreal mires are the blocking of ditches to re-create the high water table level, and the removal of excess trees to reduce the transpiration rate and reinstate the landscape typical of natural mires (e.g., Tarvainen et al., 2013). Most research on mire restoration has concentrated on the restoration of peat harvesting areas, which presents quite a different starting point for restoration compared to forestry drainage (Chimner et al. 2017). The few existing studies on $\mathrm{C}$ gas fluxes or carbon accumulation rates on restored peat harvesting areas (e.g. Tuittila et al. 1999; Waddington et al. 2010; Strack, Zuback, 2013; Wilson et al. 2016) and forestry drained mires (Komulainen et al. 1998, 1999; Urbanová et al. 2012; Kareksela et al. 2015; Koskinen et al. 2016) indicate

91 that the rising water table increases the rate of field layer photosynthesis, decreases $\mathrm{CO}_{2}$ efflux and increases $\mathrm{CH}_{4}$ emissions, thereby partially or fully restoring natural mire functions. 
94 Projected global warming in northern latitudes (IPCC 2013) is going to have its own impact 95 on mire GHG exchange. Experimental warming studies on mires have been carried out with 96 increasing frequency since 2000 (e.g. Wiedermann et al. 2007; Turetsky et al. 2008;

97 Dorrepaal et al. 2009; Chivers et al. 2009; Johnson et al. 2013; Ward et al. 2013; Munir, 98 Strack 2014; Pearson et al. 2015; Peltoniemi et al. 2016; Voigt et al. 2017; Gill et al. 2017; 99 Mäkiranta et al. 2018). These studies, which mostly use open top chambers (OTC's), have 100 shown varied responses of vegetation, microbial communities and gas fluxes to warming 101 within a few years' study periods. In most cases warming has increased respiration, but the impact on photosynthesis and methane emissions has been context dependent and strongly influenced by species composition and water table level: under wet conditions these fluxes

104 may increase, while, under dry conditions and lower water table, in most cases,

105 photosynthesis and methane emissions either decrease or remain unchanged (Turetsky et al. 106 2008; Dorrepaal et al. 2009; Ward et al. 2013; Munir, Strack 2014; Pearson et al. 2015;

107 Peltoniemi et al. 2016; Gill et al. 2017; Voigt et al. 2017). Denitrification and consequently $108 \mathrm{~N}_{2} \mathrm{O}$ fluxes have high temperature sensitivity (Butterbach-Bahl et al. 2013) due to which 109 warming should increase $\mathrm{N}_{2} \mathrm{O}$ emissions. This far there have been only a few studies

110 including warming impacts on $\mathrm{N}_{2} \mathrm{O}$ emission, and in these, either no changes (Ward et al.

111 2013, Pearson et al. 2015) or increased emissions (Voigt et al. 2017) have been observed.

112 Further, how warming impacts GHG exchange under different land uses

113 (drainage/restoration) have not been documented in mires thus far.

115 Our aim is to quantify how forestry drainage and restoration impact GHG dynamics and 116 whether the effects of moderate warming differ between the land uses. To tease out the direct 
117 impact of warming we measured $\mathrm{CO}_{2}, \mathrm{CH}_{4}$ and $\mathrm{N}_{2} \mathrm{O}$ fluxes, and leaf area development at six

118 wetlands with peat or primary mires (sensu Joosten et al. 2017) over two growing seasons.

119 Primary mires are successionally young wetlands that, under suitable climatic conditions, will

120 develop into deep peat mires (Tuittila et al. 2013; Joosten et al. 2017) and they are known to

121 rapidly respond to climatic variation (Laitinen et al. 2008; Leppälä et al. 2011a). Four of the

122 sites have experienced long-term water table drawdown due to ditching for forestry in the

1231970 s, while restoration of two of these sites in 2008 raised water table levels back to the same

124 level as in the two undrained (control) sites (see Laine et al. 2016). Open top chambers (OTC)

125 were used to warm the plots.

127 We hypothesized that 1) drainage increases $\mathrm{CO}_{2}$ and $\mathrm{N}_{2} \mathrm{O}$ release and decreases $\mathrm{CH}_{4}$ emissions 128 in comparison to undrained sites. 2) Restoration returns ecosystem functions back to the level

129 of undrained sites rapidly $\left(<5\right.$ years); this means that the restored sites are $\mathrm{CO}_{2}$ sinks, $\mathrm{CH}_{4}$

130 emitters and have very low $\mathrm{N}_{2} \mathrm{O}$ emissions. 3) Warming promotes ecosystem respiration but

131 the response of photosynthesis and methane emissions depends on the prevailing hydrology;

132 under undrained and restored conditions warming increases photosynthesis and methane 133 emissions, but under drained conditions these functions remain unchanged. 4) Warming 134 promotes $\mathrm{N}_{2} \mathrm{O}$ emissions.

\section{Material and methods}

\subsection{Study area}

138 The study was carried out on the Finnish coast of the Gulf of Bothnia in Siikajoki (drained and restored sites: $\sim 64^{\circ} 48^{\prime} 93 \mathrm{~N}, 24^{\circ} 37^{\prime} 39 \mathrm{E}$; undrained sites: $\left.64^{\circ} 46^{\prime} 91 \mathrm{~N}, 2^{\circ} 38^{\prime} 65 \mathrm{E}\right)$. We 
140 selected six primary mires belonging to three land use categories: two undrained (UD1,

141 UD2), two forestry drained in 1970's (D1, D2), and two drained (1970's) sites restored in

1422008 (R1, R2). The drainage of site D2 had not resulted in effective regime shift towards

143 forested ecosystem, and the water table was clearly higher than at D1 (see Laine et al. 2016).

144 Restoration was carried out by felling most trees so that $\sim 0-5$ trees were left per $100 \mathrm{~m}^{2}$, and

145 blocking ditches with soil excavated near the ditches. The sites have been formed in the coast

146 following post-glacial land uplift approximately 100-200 years ago (Ekman 1996). They are

147 located 1.5 - $2 \mathrm{~m}$ above sea level in small ( $\sim 0.5-3 \mathrm{ha})$ depressions between nutrient-poor sand

148 dunes. The organic soil layer laying over sand is only 5-10 cm thick and the organic matter

149 content of the top $10 \mathrm{~cm}$ at the undrained sites varies from 25 to $46 \%$, with $\mathrm{pH}$ of 6.3 to 6.6

150 (Merilä et al. 2006). The sand underneath the organic soil has aeolian origin, it is nutrient

151 poor and has particle size of $\sim 0.17 \mathrm{~mm}$ (Hellemaa 1998). The length of growing season in the

152 area is 150 days, the 30 -yr average annual temperature $2.6{ }^{\circ} \mathrm{C}$, and the average annual

153 precipitation $541 \mathrm{~mm}$ (Revonlahti weather station, Siikajoki, $64^{\circ} 41^{\prime} \mathrm{N}, 25^{\circ} 05^{\prime} \mathrm{E}, 48 \mathrm{~m}$ a.s.l.;

154 Pirinen et al. 2012; see Table 1 for more climate details).

156 Based on differences in tree stand and hydrology, the originally drained sites were divided

157 into two groups. Sites D1 and R1 (group 1) had successful drainage results with clearly

158 increased tree growth, while sites D2 and R2 (group 2) had only sparse tree stands.

159 Additionally, the undrained control sites were assigned into these two groups but based on

160 their terrestrial age, so that the younger site (age $\sim 100 \mathrm{yr}$ ), UD1, was assigned to group 1 and

161 the slightly older site (age $\sim 150 \mathrm{yr}$ ), UD2, to group 2 . The undrained sites are open treeless

162 wetlands with the field layer (including small shrubs, herbaceous plants and moss layer) plant

163 community composed of graminoids (Carex nigra, C. canescens) and forbs (Comarum

164 palustre, Equisetum fluviatile, Peucedanum palustre). The moss layer is composed mainly of 
165 Warnstorfia exannulata and Calliergon species, while some patches of Sphagnum mosses

166 (e.g. S. squarrosum, S. fimbriatum) can also be found. At drained sites, the field layer

167 vegetation is dominated by shrubs (Vaccinium uliginosum, V. vitis-idaea, Salix repens) and

168 feather mosses (Pleurozium shreberii, Polytrichum commune), although at D2 sedges (Carex

169 nigra, C. canescens) are also abundant. The restored sites are open, with only few scattered

170 trees; at the field layer sedges (Carex nigra, C. canescens) form the majority of the

171 vegetation and shrubs (e.g. Salix repens) are common. Moss layer is sparse and Warnstorfia

172 exannulata occurs with remnants of e.g. Pleurozium schreberi and Polytrichum strictum. For

173 more details on vegetation composition, see Laine et al. (2016).

175 At each site, we established ten permanent sample plots and assigned half of them to a

176 warming experiment, covering them with open top chambers (OTC). OTC is a passive

177 warming method that aims at a moderate warming impact of $1-3{ }^{\circ} \mathrm{C}$. The remaining five plots

178 at each site are the ambient temperature (ambient-T) plots. The first set of OTCs was installed

179 in autumn 2008 to sites UD2, D2 and R2 and the second set was installed in spring 2011 to

180 sites UD1, D1 and R1. The OTCs were constructed from durable transparent polycarbonate

181 and had a projected area of $1.5 \mathrm{~m}^{2}$ (see Pearson et al. 2015). They were removed from the

182 plots during the typical snow-covered period (November-April) to maintain natural snow

183 cover. Soil temperature at 5 and $15 \mathrm{~cm}$ depth and air temperature at $30 \mathrm{~cm}$ height were

184 monitored continuously within each sample plot at $2 \mathrm{~h}$ time step during the snow free period

185 (iButton, Maxim Integrated, U.S.). At the beginning of May 2011, a month before the first

186 gas flux measurements, square aluminium collars $(58 \times 58 \mathrm{~cm})$ were permanently inserted

187 into sample plots to support gas flux measurements. The collar rim reached about $15 \mathrm{~cm}$ into

188 the soil, but the deeper roots of trees and vascular plants were left intact. Sample plots were

189 surrounded by boardwalk platforms to avoid trampling. 
192 We performed weekly to biweekly $\mathrm{CO}_{2}$ flux measurements from June to November in 2011

193 and from May to November in 2013, i.e. three and five years after restoration. Monthly

194 methane $\left(\mathrm{CH}_{4}\right)$ fluxes were measured from May - September 2011 and June to August 2013.

195 Monthly nitrous oxide $\left(\mathrm{N}_{2} \mathrm{O}\right)$ fluxes were measured from May to September 2011. Seasonal

196 development of field layer leaf area index (LAI) was monitored during the 2011 and 2013

197 growing seasons. To facilitate gas flux measurements, the OTC's were lifted up from the

198 warmed plot for the duration of the measurement (15 to 30 minutes).

$200 \mathbf{C O}_{2}$ flux was measured with a transparent plastic chamber $(60 \times 60 \times 30 \mathrm{~cm})$ that was

201 connected to a portable infrared gas analyser (EGM-4, PP Systems, UK). The chamber was

202 equipped with a fan and a cooling system that maintained the air temperature within $2^{\circ} \mathrm{C}$ of

203 ambient (Alm et al. 2007). Two to three study sites were measured within the same day,

204 typically between 9 a.m. and 5 p.m. At each sample plot measurements were made under

205 ambient stable light, with the chamber shaded by a mesh fabric to decrease the photosynthetic

206 photon flux density (PPFD) level, and with chamber covered by an opaque shroud (PPFD 0).

207 Each measurement lasted 90-180s. The chamber was lifted and ventilated between

208 measurements to restore the ambient $\mathrm{CO}_{2}$ concentration. During the measurements,

209 headspace $\mathrm{CO}_{2}$ concentration, photon flux density (PPFD) and chamber temperature were

210 recorded at 15 s intervals. 
212 The net ecosystem $\mathrm{CO}_{2}$ exchange (NEE) was calculated from the linear change in $\mathrm{CO}_{2}$

213 concentration in chamber headspace, as a function of the chamber headspace volume and

214 mean chamber air temperature during the measurement. Dark measurements were used as an

215 estimate of instantaneous ecosystem respiration (Reco). Gross photosynthesis (PG) was

216 calculated by subtracting NEE rate measured in full light and shaded conditions from the

217 subsequent dark measurement (e.g. Alm 2007). Our sign convention shows positive NEE

218 when the ecosystem is a $\mathrm{CO}_{2}$ sink from the atmosphere.

Methane $\left(\mathrm{CH}_{4}\right)$ and nitrous oxide $\left(\mathrm{N}_{2} \mathrm{O}\right)$ fluxes were measured with opaque chambers (60x60x30cm), equipped with fans for air circulation. Four $60 \mathrm{ml}$ gas samples were taken from the chamber with plastic syringes at 5, 15, 25 and 35 minutes after closure. Samples were stored in $12 \mathrm{ml}$ glass vials until analysis. Chamber headspace temperature was monitored during measurements.

Samples from 2011 were analysed for $\mathrm{CH}_{4}$ and $\mathrm{N}_{2} \mathrm{O}$ in the Natural Resources Institute of

227 Finland laboratory at Vantaa, using an Agilent Technologies 7980A gas chromatograph. Samples from 2013 were analysed for $\mathrm{CH}_{4}$ at the Hyytiälä Forestry Field Station, Finland, using a HP-5890A gas chromatograph. $\mathrm{CH}_{4}$ and $\mathrm{N}_{2} \mathrm{O}$ fluxes were calculated from the linear change in chamber headspace gas concentration as a function of headspace area, volume and mean headspace temperature during the measurement. The correlations $\left(\mathrm{r}^{2}\right)$ of the linear change in gas concentrations were generally above 0.9 and 0.8 for $\mathrm{CH}_{4}$ and $\mathrm{N}_{2} \mathrm{O}$ respectively; however, when flux rates were near zero (ranging from $-0.05-+0.03 \mathrm{mg} \mathrm{m}^{-2} \mathrm{~h}^{-1}$ ), lower $\mathrm{r}^{2}$ were typical and these fluxes were not rejected. We rejected only the measurements that

235 where clearly non-linear, without being near zero, altogether $2 \%$ of the measurements. 
237 Field layer vascular plant leaf area index (LAI) was measured six and seven times during 238 years 2011 and 2013, respectively. Within each sample plot, five $8 * 8 \mathrm{~cm}$ sub-plots were 239 established and the number of leaves of each vascular plant species was counted every three

240 weeks. At the same time leaves of each species were collected outside the gas flux plots,

241 carefully mounted on paper and scanned. Leaf area was digitally analysed from the images.

242 We calculated LAI of each species as a product of the number of leaves and the average leaf

243 size. Seasonal LAI development was estimated with statistical modelling, see section 2.4.1.

245 Supporting measurements of soil temperature and water table level were made during gas

246 flux campaigns. During flux measurements, we manually measured soil temperature at 5, 10

247 and $15 \mathrm{~cm}$ depth next to each sample plot and measured water table level using perforated

248 pipes that were inserted into the soil at close vicinity of the sample plots. Soil or moss surface

249 was used as the zero reference level.

\subsection{Carbon sequestration of the tree stand}

252 Tree stand characteristics were measured in 2005, 2009 and 2013 at 12 and 14 permanent

253 circular plots at sites all sites. The number of all trees taller than $1.3 \mathrm{~m}$ and diameter at breast

254 height $\left(D_{\text {bh }}\right)$ more than $45 \mathrm{~mm}$ was counted and $D_{\text {bh }}$ of all trees was measured. For each

255 species we chose the tree with largest $D_{\text {bh }}$ and at least one tree from diameter classes 10 - 20

$256 \mathrm{~cm}$ and $4.5-10 \mathrm{~cm}$ as sample trees. From these sample trees height $(\mathrm{h})$ and living crown

257 length and width were measured. Based on these data we calculated the stand density (trees

$258 \mathrm{ha}^{-1}$ ) and annual volume increment with the KPL software (Heinonen, 1994). 
260 While the tree stand of undrained and restored sites was either absent or minor, at drained

261 sites the carbon sequestration of the tree stand was estimated as follows: To calculate the

262 above- and belowground biomass for birches and pines separately, we used species-specific

263 models developed by Repola, $(2008 ; 2009)$. Above ground biomass estimates were based on

$264 D_{\text {bh }}$ and tree height, while the below ground biomass estimates were based on $D_{\text {bh. }}$ The tree

265 stand biomass difference between years 2013 and 2005 was used to calculate the annual

266 biomass increment and converted it to carbon using the frequently applied conversion factor

2670.50 (see e.g. Laiho, Laine 1997).

\subsection{Data analysis}

270 We applied linear and nonlinear hierarchical mixed-effects modelling to quantify how long-

271 term drainage, restoration and moderate warming impact LAI development and GHG flux

272 dynamics of the field layer of the primary mires. We used two steps in the gas flux

273 modelling. First, we related gas flux parameters (e.g. PMAX and Reco, see Eq. 4 below) to

274 so-called stable factors, namely land use category, warming treatment, year and site group

275 (group 1: UD1, D1 and R1; group 2: UD2, D2 and R2). Then we built so-called "full models"

276 that also included environmental variables (temperature, LAI etc.) as explanatory variables of

277 the gas flux parameters. The model building was based on known properties of the natural

278 process, where the effects of treatments and environmental factors on the model parameters

279 were concurrently analysed and added sequentially to the model in order of importance. The

280 prediction of the LAI model is included as an environmental variable in the $\mathrm{CO}_{2}$ and $\mathrm{CH}_{4}$

281 models. 


\subsubsection{LAI modelling}

284 Seasonal LAI development can be described with a log-normal unimodal function with 285 parameters for maximum leaf area $\left(\mathrm{LMAX}_{\mathrm{ijk}}\right)$ and timing of maximum leaf area $\left(\mathrm{DMAX}_{\mathrm{ijk}}\right)$.

286 Our modelling procedure follows that presented by Mäkiranta et al. (2017).

287

$y_{i j k l}=L M A X_{i j k} \times \exp \left[-0.5\left(\frac{\log \left(\frac{T_{i j k l}}{D M A X_{i j k}}\right)}{G_{i j k}}\right)^{2}\right]+e_{i j k} ; L M A X_{i j k}, D M A X_{i j k}, G_{i j k}>0$

288 where $\mathrm{y}_{\mathrm{ijkl}}$ is the observed LAI $\left(\mathrm{m}^{2} \mathrm{~m}^{-2}\right)$ at light level 1 within year $\mathrm{k}$ within plot $\mathrm{j}$ within site $\mathrm{i}$,

289 and the predictor $\mathrm{T}_{\mathrm{ijkl}}$ is the corresponding Julian days since the beginning of year. The

290 parameters of the model are the maximum LAI $\left(\operatorname{LMAX}_{\mathrm{ijk}}\right)$, its timing $\left(\mathrm{DMAX}_{\mathrm{ijk}}\right)$, and the

291 scale parameter $G_{i j k}$, which is related to the temporal scale of LAI development. The

292 residuals ( $\mathrm{e}_{\mathrm{ijk}}$ ) did not show signs of inconstant variability and temporal autocorrelation, and

293 it was therefore assumed that they are independent with zero mean and common variance

$294\left(\sigma^{2}\right)$. To quantify the impacts of treatments on the LAI parameters, they were further written

295 as linear functions of fixed predictors (land use, warming, year and site group) and three

296 nested random effects for site, plot within site, and year within plot within site. Logarithmic

297 form was used to ensure positive values of parameters in all cases. The resulting submodels

298 are:

299

$L M A X_{i j k}=\exp \left(\boldsymbol{\beta}^{L \boldsymbol{M A X}}, \boldsymbol{x}_{i j \boldsymbol{k}} \boldsymbol{L M A X}_{+}{a_{i}}^{L M A X}+b_{i j}{ }^{L M A X}+c_{i j k}{ }^{L M A X}\right)$

300

$D M A X_{i j k}=\exp \left(\boldsymbol{\beta}^{\mathbf{D M A X}}, \boldsymbol{x}_{i j k} \boldsymbol{D M A X}+a_{i}{ }^{D M A X}+b_{i j}{ }^{D M A X}+c_{i j k} D M A X\right)$

301

$G_{i j k}=\exp \left(\boldsymbol{\beta}^{\boldsymbol{G}}, \boldsymbol{x}_{i j k}{ }^{\boldsymbol{G}}+a_{i}{ }^{G}+b_{i j}{ }^{G}+c_{i j k}{ }^{G}\right)$ 


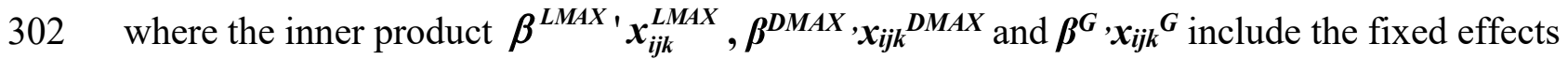

303 of the treatments on LMAX and DMAX (the terms included in the final models will be

304 shown in result tables). The normally distributed random effects for different parameters at

305 the same level (e.g. $a_{i}{ }^{\operatorname{LAX}}, a_{i}{ }^{D M A X}, a_{i}{ }^{G}$ ) were assumed to be uncorrelated to achieve

306 convergence (Pinheiro and Bates 2000). They modelled the variability that was not explained

307 by the fixed effects, and simultaneously the dependence due to grouping in the data.

308 Submodels (2 and 3) were included in Equation 1 and the resulting model was fitted in one

309 step. We used approximate conditional F- tests (Pinheiro, Bates 2000) and Akaike

310 information criterion (AIC) in model selection. Models were fitted using the nlme package of

311 R (R Core Team 2016), following Pinheiro and Bates (2000). To facilitate $\mathrm{CH}_{4}$ flux

312 modelling, we also used the same method to model the LAI of species with aerenchyma

313 (mainly sedges in our sites) (LAI_S). See Supporting information 1 for model details.

\section{$314 \quad$ 2.4.2. $\mathrm{CO}_{2}$ flux modelling}

315 To determine the effects of land use and warming on the light response parameters of

316 photosynthesis, and their dependences to environmental factors (LAI, air temperature, soil

317 temperature) we applied a nonlinear mixed-effects model with the hyperbolic light saturation

318 curve (e.g. Lappi, Oker-Blom 1992):

$319 A_{i j k l m}=R_{e c o i j k l}+\frac{P M A X_{i j k l} P P F D_{i j k l m}}{\alpha_{i j k l}+P P F D_{i j k l m}}+e_{i j k l m}$

320 where the response $A_{i j k l m}$ is the observed NEE $\left(\mathrm{mg} \mathrm{m}^{-2} \mathrm{~h}^{-1}\right)$, and the predictor $P P F D_{i j k l m}$ is the

321 photosynthetic photon flux density $\left(\mu \mathrm{mol} \mathrm{m} \mathrm{m}^{-2} \mathrm{~s}^{-1}\right)$ on measurement $m$ of day $l$ of year $k$ of plot

$322 j$ at site $i$. The parameters to be estimated are respiration $\left(\operatorname{Reco}_{i j k l}\right)$, photosynthetic capacity

323 i.e. the maximum rate of light-saturated gross photosynthesis $\left(P M A X_{i j k l}\right)$ and the maximum

324 quantum yield of $\mathrm{CO}_{2}$ assimilation $\left(\alpha_{i j k l}\right)$, i.e., light use efficiency at low light. The residual

$325\left(e_{i j k l m}\right)$ is normally distributed with mean zero and constant variance. Parameters $P M A X_{i j k l}$, 
$326 R e c o_{i j k l}$ and $\alpha_{i j k l}$ were written as linear functions of fixed predictors and random effects. These

327 submodels are:

$328 P M A X_{i j k l}=\exp \left(\boldsymbol{\beta}^{\boldsymbol{P M A X}}, \boldsymbol{x}_{i j k l} \boldsymbol{P M A X}_{+a_{i}}^{P M A X}+b_{i j}{ }^{P M A X}+c_{i j k}{ }^{P M A X}+d_{i j k l}{ }^{P M A X}\right)$

$R e c o_{i j k l}=\exp \left(\boldsymbol{\beta}^{\boldsymbol{R}}, \boldsymbol{x}_{i j k l} \boldsymbol{R}+a_{i}^{R}+b_{i j}{ }^{R}+c_{i j k}{ }^{R}+d_{i j k l}{ }^{R}\right)$

$\alpha_{i j k l}=\exp \left(\boldsymbol{\beta}^{\alpha}, \boldsymbol{x}_{i j k l}{ }^{\alpha}+a_{i}{ }^{\alpha}+b_{i j}{ }^{\alpha}+c_{i j k}{ }^{\alpha}+d_{i j k l}{ }^{\alpha}\right)$

331

332 The random effects $\left(a_{i}^{P M A X}+b_{i j}^{P M A X}, \ldots, c_{i j k}{ }^{\alpha}+d_{i j k l}{ }^{\alpha}\right)$ were assumed to have mean zero and common variance; the effects for different parameters at the same level were assumed to be uncorrelated. In practice, the model building started with a model without predictors and with random effects $d_{i j k l}$ only. The predictor that showed strongest relationship with the random effects was thereafter included in the fixed part using appropriate transformation and the model was re-estimated. The random effects of the updated model were extracted and their relationship was again explored against the current and potential new predictors. These steps were iterated until the random effects did not show any unexplained trends. The final model was then fitted using the above-specified full random effect structure and the fixed effects were tested using conditional approximate F- tests on the fixed effects $(p>0.05)$. The number of replicates in our data is small, and therefore the effects of land use or warming needs to be very large to become statistically significant. To maximally utilize our data and provide essential information for future research efforts, we therefore report parameter estimates from the full model and their confidence intervals regardless of their p-values, as in Mäkiranta et al. (2017).

To separate the impacts of land use category and warming treatments from those of environmental variables, we used two sets of fixed predictors (e.g. $\left.\boldsymbol{\beta}^{P M A X}{ }^{{ }^{\prime}} \boldsymbol{x}_{i j k l}^{P M A X}\right)$ in the submodels (eq. 5-7). The first set included only categorical treatment effects, while the second 
351 set also included environmental variables. For the first set, the categorical predictors were

352 land use, warming, measurement year and site group. For the second set, the following

353 environmental variables and their transformations were included to form the full model of

354 PMAX $_{\mathrm{ijk} 1}$ : LAI was included as transformation LAI2 $=\ln (1-\exp (-\mathrm{LAI}))$ to take into account

355 the self-shading of leaves through Beer-Lambert's law (Wilson 1959). Air temperature was

356 included using a three-knot spline, with knots placed at $15^{\circ} \mathrm{C}, 20^{\circ} \mathrm{C}$ and $25^{\circ} \mathrm{C}$ (Harrell 2001),

357 which allowed an optimum temperature within the range of observations $\left(0-37^{\circ} \mathrm{C}\right)$. The full

358 model of $\mathrm{R}_{\mathrm{ijkl}}$ included the predicted plot-specific LAI from model (1) in logarithmic form,

359 i.e., respiration was assumed to be linearly related to LAI. Air temperature was used in linear

360 form, which implies an exponential response of respiration to temperature. In addition to air

361 temperature, $15-\mathrm{cm}$ soil temperature was included in the $\mathrm{R}_{\mathrm{ijkl}}$ models in form with a minimum

362 at $10^{\circ} \mathrm{C}$, which allows exponential response to soil temperatures below $10^{\circ} \mathrm{C}$. For the

363 submodel of parameter $\alpha_{\mathrm{ijkl}}$ (eq. 7), only land use category was used as a fixed predictor. The

364 chosen transformations provided better fits to the data than non-transformed or

365 logarithmically transformed predictors, and satisfactorily modelled all clear trends from the

366 random effects. See Supporting information 2 for model details.

\subsection{3. $\mathrm{CH}_{4}$ and $\mathrm{N}_{2} \mathrm{O}$ flux modelling:}

369 We used linear mixed-effects models to analyze the effects of land use and warming on $\mathrm{CH}_{4}$ and $\mathrm{N}_{2} \mathrm{O}$ fluxes, and their dependences on environmental variables. Inverse transformation, $1 /\left(\mathrm{CH}_{4}+0.3\right)$, was used for $\mathrm{CH}_{4}$ to homogenize the residual variance of the model (Appendix

372 3). Similar to $\mathrm{CO}_{2}$ modelling, in the first $\mathrm{CH}_{4}$ and $\mathrm{N}_{2} \mathrm{O}$ modelling steps we included

373 categorical treatment effects as fixed predictors. These were land use category, warming,

374 their interaction, year and site group. In the second step, we formed the full model that also 
includes environmental variables. For $\mathrm{CH}_{4}$ flux, the full model included sedge LAI (LAI_S),

376

377 air temperature (Ta), soil temperature at $5 \mathrm{~cm}$ (T5) and water table depth (WT), which was included using a three-knot spline, with knots placed at values $-55,-40$ and $-25 \mathrm{~cm}$ (Harrell 2001), which allowed an optimum water table within the range of observations $(-80 \mathrm{~cm}-0$ $\mathrm{cm})$. For $\mathrm{N}_{2} \mathrm{O}$ flux, the full model included total LAI, WT, Ta and T5. Random intercepts were assumed for levels site and plot and measurement time. The plots were nested within sites and crossed with measurement time. See Supporting information 3 and 4 for model details.

\subsection{Reconstructing seasonal cumulative gas fluxes}

We used the fixed part of the full models of $\mathrm{CO}_{2}$ (eq. 4-7) and $\mathrm{CH}_{4}$, described earlier, to estimate the seasonal cumulative fluxes of NEE and $\mathrm{CH}_{4}$. Reconstructions were made with hourly time step and results are reported per square meter. The environmental data for reconstructions was attained as follows: hourly values of PPFD from the Siikajoki, Ruukki weather station $\left(64^{\circ} 68^{\prime} \mathrm{N}, 25^{\circ} 09^{\prime} \mathrm{E}\right.$, Finnish Meteorological Institute). PPFD under the forest canopy in site D1 was estimated as in Badorek et al. (2011). Tree canopy leaf area (CLAI) for the calculations was estimated using the biomass equations of Repola $(2008,2009)$ for Scots pine and birch, and the specific leaf areas of $11 \mathrm{~m}^{2} \mathrm{~kg}^{-1} \mathrm{DW}$ for pine (Luoma 1997), and 25 $\mathrm{m}^{2} \mathrm{~kg}^{-1} \mathrm{DW}$ for birch (Parviainen 1999). Soil temperature at 5 and $15 \mathrm{~cm}$ depth and air temperature at $30 \mathrm{~cm}$ height were continuously recorded beside each sample plot at $2 \mathrm{~h}$ time step (iButton, Maxim Integrated, U.S.) and interpolated to hourly values, and averages of warmed and ambient-T plots were calculated for each site. Water table was measured during gas flux campaigns, on average once per week. This data was linearly interpolated into hourly 
values and site averages were calculated. Hourly LAI was predicted using the fixed part of the LAI model for warming and ambient-T plots of each site.

401 We reconstructed fluxes for 1 May to 30 September. We had continuous environmental data 402 from 10 May to 30 September for 2011 and from 14 May to 30 September for 2013. For the 403 beginning of May, we multiplied the average May flux rate by the number of missing hours.

404 We acknowledge that gas exchange occurs also during time period not included here. As $\mathrm{N}_{2} \mathrm{O}$

405 flux rates per site were rather constant and not explained by any environmental variable, we 406 estimated the seasonal cumulative flux by multiplying the average flux rate by the number of 407 hours during 1 May to 30 September.

\section{Global warming potentials (GWP)}

409 In order to compare the GHG balance of the different land uses, we calculated the GWP's for 410 each site for growing seasons 2011 and 2013, based on a 100-year time horizon. We used the 411 cumulative seasonal $\mathrm{NEE}, \mathrm{CH}_{4}$ and $\mathrm{N}_{2} \mathrm{O}$ fluxes calculated per site and included the carbon 412 sequestration of the tree stand in the NEE of drained sites by adding the estimated annual $413 \mathrm{CO}_{2}$ sequestration. GWP's were not calculated for the warming treatment plots as those 414 would not include the response of tree stand to warming. In addition, the $\mathrm{N}_{2} \mathrm{O}$ flux estimates 415 from season 2011 were used for 2013. The cumulative seasonal $\mathrm{CO}_{2}, \mathrm{CH}_{4}$ and $\mathrm{N}_{2} \mathrm{O}$ flux 416 estimates were multiplied by 1,28 and 265 , respectively to convert all to $\mathrm{CO}_{2}$-equivalent 417 fluxes that can be summed (Myhre et al 2013). Negative GWP values indicate a net cooling 418 effect on the climate and positive values indicate a net warming effect. 
422 The average WT in the undrained sites was -8 and $-27 \mathrm{~cm}$, in the restored sites -11 and -24

$423 \mathrm{~cm}$, and in the drained sites -28 and $-41 \mathrm{~cm}$ during years 2011 and 2013, respectively,

424 (negative values indicate belowground WT). The two drained sites differed from each other,

425 so that D2 had shallower WT than D1 in both years (Fig. 1). During late summer 2013 all

426 sites experienced very low WT for an extended period (Fig. 1b).

428 Open top chambers (OTC) increased average air temperatures by $1.4^{\circ} \mathrm{C}$ compared to 429 ambient-T plots. The difference between OTC and Ambient-T plots was higher during spring

$430 \quad\left(1.8^{\circ} \mathrm{C}\right)$ and summer $\left(1.6^{\circ} \mathrm{C}\right)$ than during autumn $\left(0.5^{\circ} \mathrm{C}\right)($ Table 1$)$. Average soil

431 temperatures were not elevated by the OTCs (Table 1). Annual and summer average

432 temperatures were higher, and precipitation slightly higher, in years 2011 and 2013 than the 433 long term averages (Table 2).

\subsection{Leaf area index}

435 Land use had a clear impact on LMAX as it was lower in drained sites and at the comparable

436 level in restored and undrained sites (Fig. 2, Table S1.1.). Warming treatment increased

437 LMAX on average by $0.4 \mathrm{~m}^{2} \mathrm{~m}^{-2}$, and LMAX was lower in year 2013 than in 2011 (Fig.2,

438 Table S1.2.). The timing of the LMAX (LMAX_T) was dependent on land use and year

439 (Table S1.1.). LMAX was attained earlier in restored sites than in undrained sites and earlier

440 in year 2013 than in 2011 (Table S1.2.). The site groups 1 and 2 did not differ from each

441 other (Table S1.2.)

\subsection{1. $\mathrm{CO}_{2}$ exchange}


444 At the ambient-T plots, average field layer gross photosynthesis at full light (PPFD>800)

445 ranged from 537 to $1116 \mathrm{mg} \mathrm{CO}_{2} \mathrm{~m}^{-2} \mathrm{~h}^{-1}$. In the warmed plots, the range was from 657 to

$4461122 \mathrm{mg} \mathrm{CO}_{2} \mathrm{~m}^{-2} \mathrm{~h}^{-1}$. (Table 3). Average ecosystem respiration rates (Reco) ranged from 337

447 to $751 \mathrm{mg} \mathrm{CO}_{2} \mathrm{~m}^{-2} \mathrm{~h}^{-1}$. In the warmed plots, the range was from 335 to $525 \mathrm{mg} \mathrm{CO}_{2} \mathrm{~m}^{-2} \mathrm{~h}^{-1}$

448 (Table 3).

450 We based our $\mathrm{CO}_{2}$ modelling on the relationship between NEE and PPFD, which is a strong

451 controller of photosynthesis (Fig. 3). The nonlinear mixed effect models showed that $\mathrm{P}_{\mathrm{MAX}}$

452 varied between land use categories; drained sites had lower $\mathrm{P}_{\text {MAX }}$ than undrained sites (Table

453 S2.2.). Experimental warming, as such, had no impact on PMAX. (Table S2.1.) After inclusion

454 of environmental variables (i.e. the full model), the effect of land use was overridden by air

455 temperature and LAI implying that the treatment impact is dominated by changes in these

456 factors (Table S2.3. and S2.4.). The model indicated that drained sites had slightly higher

457 Reco than undrained sites, (Table S2.2.). As the- site group, i.e. group 1 with successful

458 drainage and group 2 with low drainage impact, was significant in the model, so that group 1

459 had higher Reco, the difference between properly drained site D1 and undrained sites is

460 stronger than indicated by the insignificant p-value (Table S2.2.). At the drained sites, the

461 respiration component includes tree root respiration but not respiration of the above-ground

462 parts of the trees, therefore the real Reco would be higher. The tree stand net primary

463 productivity is included in the estimate of seasonal NEE. Warming had no impact on Reco,

464 and Reco was higher in year 2013 than in 2011. In the full model, the environmental

465 variables air and soil temperature and LAI had a significant impact on Reco (Table S2.3.,

466 Table S2.4.). The maximum quantum yield of $\mathrm{CO}_{2}$ assimilation ( $\alpha$ ), i.e., the light-use

467 efficiency at low light, was lower at drained sites and similar in restored and undrained sites

468 (Table S2.2., Table S2.4.). 
469 The growing season cumulative NEE of the field layer and soil varied between -1088

470 (source) and +567 (sink) $\mathrm{g} \mathrm{CO}_{2} \mathrm{~m}^{-2}$ season $^{-1}$. Unlike in undrained and restored sites, in the

471 drained sites the tree stand also sequestered carbon. The tree stand volumes were low, being

472106 and $37 \mathrm{~m}^{3} \mathrm{ha}^{-1}$ in sites D1 and D2, respectively at year 2013. The average annual volume

473 increment since 2005 has been 5 and $2 \mathrm{~m}^{3} \mathrm{ha}^{-1}$ year-1 representing annual carbon sequestration

474 of 959 and $423 \mathrm{~g} \mathrm{CO}_{2} \mathrm{~m}^{-2}$ for sites D1 and D2, respectively. As most of the carbon

475 sequestration to the trees occurs during the growing season, we consider the annual value

476 comparable to our growing season field layer NEE estimate. At the more productive site, D1,

477 the NEE after inclusion of tree stand sequestration was about the same magnitude as in

478 undrained site, while site D2 was a strong $\mathrm{CO}_{2}$ source (Fig. 4a). Generally, all the sites varied

479 from being small sources or sinks with clear inter annual variation. NEE was lower/negative

480 during dry year 2013 and higher under warming treatment than under ambient-T conditions 481 (Fig. 4a).

\subsubsection{Methane emissions}

484 The average measured $\mathrm{CH}_{4}$ emissions varied between land use and warming treatments from

4850.21 to $1.00 \mathrm{mg} \mathrm{CH}_{4} \mathrm{~m}^{-2} \mathrm{~h}^{-1}$ (Table 3). The monthly variation in flux rates was rather large,

486 with highest fluxes in early summer and lower fluxes in late summer and autumn (Fig. 5).

487 Drained sites had somewhat lower emissions than undrained ones. Experimental warming 488 increased $\mathrm{CH}_{4}$ flux in undrained sites, but not in restored and drained sites (Table S3.1, Table

489 S3.2.). When environmental variables were included in the model, the variation in $\mathrm{CH}_{4}$ flux 490 was explained by water table and air temperature (Fig. 6, Table S3.3.), leaving LAI with 491 insignificant effect. Seasonal $\mathrm{CH}_{4}$ emissions were lowest at drained sites (on average $0.2 \mathrm{~g}$

$492 \mathrm{CH}_{4} \mathrm{~m}^{-2}$ season $^{-1}$ ) and highest at restored sites (on average $1.5 \mathrm{~g} \mathrm{CH}_{4} \mathrm{~m}^{-2}$ season $^{-1}$ ) (Fig 4b). 


\subsection{3. $\mathrm{N}_{2} \mathrm{O}$ emissions}

495 The average measured $\mathrm{N}_{2} \mathrm{O}$ emissions varied between treatments from 0.15 to $0.27 \mathrm{mg} \mathrm{m}^{-2} \mathrm{~h}^{-1}$

496 (Fig. 7, Table 3). Drained sites had higher emissions than undrained sites and warming

497 caused a slight but statistically insignificant increase on the emission, however, less in

498 drained sites than in other sites (Table S4.2.). None of the environmental variables included

499 in the model (WT, Ta, LAI) explained the variation in flux rates (Table S4.3.). The seasonal

$500 \mathrm{~N}_{2} \mathrm{O}$ emissions were lowest at undrained sites (on average $0.6 \mathrm{~g} \mathrm{~N}_{2} \mathrm{O} \mathrm{m}{ }^{-2}$ season $^{-1}$ ) and

501 highest at drained sites (on average $0.9 \mathrm{~g} \mathrm{~N}_{2} \mathrm{O} \mathrm{m}^{-2}$ season $^{-1}$ ) (Fig 4c).

\subsubsection{Global warming potential}

503 At ambient-T conditions the GWP $\left(\mathrm{CO}_{2}\right.$ equivalent emissions) was positive, i.e., warming, at 504 most sites, and the drier year 2013 had higher GWP than 2011 (Table 4). The carbon 505 sequestration of tree stand at site D1 clearly decreased its GWP.

\section{Discussion}

507 Our experimental set-up with two references, namely the forestry drained starting point and 508 the undrained goal, allows the examination of a restoration pathway - is it going towards the

509 pristine conditions or to some new state? Our results show that restoration had led towards

510 pristine conditions by returning, within 3 years, the key ecosystem functions typical of

511 pristine mires. We found no differences in LAI or any gas flux components (PMAX, Reco,

$512 \mathrm{NEE}, \mathrm{CH}_{4}$ or $\mathrm{N}_{2} \mathrm{O}$ ) between restored and undrained sites, while the long-term forestry

513 drainage had changed all these ecosystem functions. The response of the functions to

514 restoration had same direction but was faster than what was observed from deep peat

515 Sphagnum mires also drained for forestry (Kareksela et al. 2015). 


\subsection{Field layer leaf area index}

518 At the forestry-drained state, which is the starting point for restoration, the LAI of field layer

519 vegetation was lower than at undrained state. This difference was mostly caused by a

520 decrease of sedge cover greater than the increase of shrub cover, indicating secondary

521 succession towards forest vegetation (the changes in species composition are shown at Laine et al. 2016). During secondary succession following drainage, the closing tree canopy increases the competition for light and decreases the biomass of field layer vegetation, especially in minerotrophic mires (Laine et al. 1995; Minkkinen et al. 1999). In our study, no longer than three years after restoration, LAI had already reached the range of undrained sites and vegetation composition was shifting towards that of undrained sites (Laine et al. 2016). We conclude that the largest share of the LAI change was due an increase in sedge cover (Laine et al. 2016). Sedges are known to be the first species to respond to increased water table level and light (Komulainen et al. 1999; Tuittila et al. 2000b; Graf et al. 2008).

OTC's installed at mires generally have rather modest impact on temperatures, with air temperature increasing typically less than $2^{\circ} \mathrm{C}$ and soil temperatures less than $1^{\circ} \mathrm{C}$ (Turetsky et al. 2008; Chivers et al. 2009; Johnson et al 2013; Munir, Strack 2014; Pearson et al. 2015;

534 Buttler et al 2015). Similarly, OTC's in our young primary mires increased the air temperature less than $2^{\circ} \mathrm{C}$, while soil temperature remained similar to the ambient-T plots.

536 The most evident effect of warming was the increased field layer LAI, which was observed in 537 all land use categories. This is in contrast to the study by Mäkiranta et al. (2017), who 538 observed no warming-induced changes in total leaf area in two sedge fens. The fast responses 539 of vascular plant LAI to warming at our sites may be due to the insignificant cover of 
540 Sphagnum mosses, which are known to buffer plant community responses to environmental

541 manipulations (Wiedermann et al. 2007). Warming with OTCs has been shown to increase

542 vegetation height (Cornelius et al. 2014) and Normalized Difference Vegetation Index

543 (NDVI) (Buttler et al 2015), but the impacts on vegetation cover have been highly species-

544 specific (Buttler et al 2015). As an example, dwarf shrubs and graminoids have showed a

545 greater growth response to warming than herbaceous perennials (Kudernatsch et al., 2008).

546 On the other hand, we observed increased LAI under all land use types despite their

547 differences in plant community composition. According to a meta-analysis by Elmendorf et

548 al. (2012), in tundra there is large heterogeneity in the direction and magnitude of vegetation

549 responses, depending for example on the duration of warming experiment, ambient summer

550 temperatures, and moisture status.

552 Differences in LAI between the two measurement years of our study highlight the

553 responsiveness of primary mires to short-term water table drops. The summer 2013 drought

554 caused a clear decrease in LAI across the land use categories, despite similar average

555 temperatures to summer 2011.

\section{2. $\mathrm{CO}_{2}$ exchange}

558 We found very high interannual and between site variability in the NEE of undrained sites

559 (ranging from -300 to $300 \mathrm{~g} \mathrm{CO}_{2} \mathrm{~m}^{-2}$ season $^{-1}$ ). Such interannual variation is a typical

560 phenomenon in mires, and extreme drought can switch a mire into a $\mathrm{CO}_{2}$ source (e.g. Alm et

561 al. 1999, Lund et al. 2012). When considering the wintertime $\mathrm{CO}_{2}$ emission of $\sim 130 \mathrm{~g} \mathrm{CO}_{2} \mathrm{~m}^{-}$

$562{ }^{2}$ season $^{-1}$ (estimated for the undrained sites at winter 2003/2004 by Leppälä et al. 2011b), the 
annual uptake during year 2011 fits well within the range measured from temperate and

564 boreal mires (Roulet et al., 2007; Aurela et al. 2009; Christensen et al. 2012; McVeigh et

565 al. 2014; Peichl et al. 2014; Helfter et al. 2015), while during 2013 the NEE was clearly

566 lower.

568 Higher soil respiration rates are considered the main consequence of mire drainage, as

569 decomposition in well-aerated soil is many-fold more efficient than in anoxic conditions and

570 root respiration increases along with developing tree stands (e.g. Silvola et al. 1996;

571 Minkkinen et al. 2007; Maljanen et al. 2010; Chivers et al. 2017). In accordance, we observed

572 higher ecosystem respiration (excluding aboveground tree respiration) from the drained sites,

573 particularly from the successfully drained site D1 compared to undrained ones. In addition to

574 lower water table, the sites differ from each other in that drained sites have significant

575 amount of tree roots, which are lacking from undrained sites. Based on estimate from a

576 Finnish forestry drained mire, 10 to $20 \%$ of the respiration may be produced by tree roots

577 (Minkkinen et al. 2018). In addition to increased respiration rates, drainage decreased the

578 photosynthetic capacity (PMAX) of the field layer vegetation and shifted production to the

579 growing tree stand. The low PMAX of field layer vegetation results from a combination of 1)

580 lower LAI, which is a proxy of the amount of photosynthetic tissue and therefore sets the

581 limit for photosynthesis (e.g. Barr et al. 2004; Wilson et al. 2007), and 2) the different species

582 composition due to differences in species photosynthetic capacities (e.g. Laine et al. 2016;

583 Korrensalo et al. 2016). When combined with lower light levels under the tree canopy, the

584 cumulative growing season NEE of field layer was clearly lower at the drained sites than at

585 the undrained sites, and was similar to a drained deep peat pine bog in Southern Finland

586 (Badorek et al. 2011). Including tree stand C sequestration, the well drained site D1 turned 
into a small $\mathrm{CO}_{2}$ sink during the less dry year, while the site $\mathrm{D} 2$ was a strong $\mathrm{CO}_{2}$ source

during both years. In some forestry drained mires, the growth of the tree stand has exceeded

the $\mathrm{C}$ release from the decomposing peat, resulting in a large $\mathrm{C}$ sink (e.g. Lohila et al. 2011;

590 Ojanen et al. 2013; Hommeltenberg et al. 2014; Minkkinen et al. 2018; Ojanen et al.

591 unpublished data,). All such sites have been nutrient poor but still able to support intensive

592 tree growth. The tree growth in our site D2, on the other hand, was low due to poor drainage and regular spring and autumn floods (Laine et al. 2016); this led to high $\mathrm{CO}_{2}$ emissions.

Unlike in the drained sites, we did not find any differences in PMAX, Reco and NEE between restored and undrained sites. Indeed, decreased respiration rates are an expected phenomena and a major goal of rewetting in mires (e.g. Waddington et al. 2010; Knox et al. 2015; Wilson et al. 2016).

In contrast to our hypothesis, experimental warming increased NEE, i.e. $\mathrm{CO}_{2}$ sink capacity in

601 all land use types. The magnitude of the warming impact was, however, secondary to that of

602 land use induced water table alteration. Biochemical processes linked with photosynthesis are controlled by temperature (e.g. Medlyn et al. 2002) and the importance of temperature in controlling respiration in mires has been well documented (e.g. Lafleur et al. 2005; Mäkiranta et al. 2009). Correspondingly, we found that both components of $\mathrm{CO}_{2}$ exchange, PMAX and

606 Reco, were dependent on air temperature. However, the impact of warming was seen only 607 after the instantaneous measured flux rates were reconstructed to cumulative growing season 608 fluxes. As OTC's were lifted up during the instantaneous measurements, they are made under 609 ambient temperature conditions, which are similar at both OTC and ambient-T plots and not 610 influenced by the OTC warming except via the indirect effect of increased leaf area. In 
611 several other studies moderate warming has had very small or no impact on $\mathrm{CO}_{2}$ fluxes

612 (Chivers et al. 2009; Johnson et al. 2013; Pearson et al. 2015), while some have reported a

613 moderate increase in respiration (Ward et al. 2013). Voigt et al. (2017) observed clear

614 decrease in NEE, as, in addition to increased ecosystem respiration, plants were suffering

615 from increased water deficient due to warming. Ward et al. (2013) noticed that the response

616 was dependent on the existing plant groups so that NEE increased only when graminoids

617 were removed, leaving only shrubs and mosses. In our sites, plants seemed to be able to

618 respond to warming by increasing leaf area and photosynthesis and we observed quite similar

619 increases in cumulative NEE due to warming in shrub-dominated drained sites and

620 graminoid-dominated undrained and restored sites.

623 Methane emissions were at the low end of those measured from different fens (e.g. Suyker et al. 1996; Rinne et al. 2007; Nilsson et al. 2008; Leppälä et al. 2011c; Trudeau et al. 2013). Similar to previous findings, $\mathrm{CH}_{4}$ emissions were controlled by water table and air temperature (e.g. Moore, Dalva 1993; Bubier et al. 1993; Pelletier et al. 2007; Lai 2009).

627 Water table and air temperature overruled any effects of LAI in explaining the $\mathrm{CH}_{4}$

628 emissions, even though vegetation functions as a supply of organic material for methanogens and as a pathway of methane through the aerobic peat layer (Ström et al. 2003; Garnet et al. 2005).

632 While the literature shows that drainage decreases or ceases $\mathrm{CH}_{4}$ emissions (Martikainen et 633 al. 1995; Roulet, Moore 1995; Maljanen et al. 2010; Frolking et al. 2011), we found only 634 slightly lower $\mathrm{CH}_{4}$ emissions from drained sites compared to undrained ones. This small 
635 difference is likely a result of the low water table throughout most of the studied growing

636 seasons at all sites. When comparing our measurements with previous study from the same

637 undrained sites it is evident that the low water table had decreased the $\mathrm{CH}_{4}$ fluxes: during a

638 wet year (2004), the seasonal cumulative $\mathrm{CH}_{4}$ emission was much higher than during our

639 measurement years (8.8 compared to $0.8 \mathrm{~g} \mathrm{CH}_{4} \mathrm{~m}^{-2}$ season ${ }^{-1}$; Fig. 4b, Leppälä et al. 2011c).

640 Mire restoration is often associated with highly increased methane emission, although there is

641 a large range of emissions $\left(0-91 \mathrm{~g} \mathrm{CH}_{4} \mathrm{~m}^{-2} \mathrm{yr}^{-1}\right)$ between the studies, caused by differences in

642 water table, vegetation composition and time since restoration (Knox et al. 2014; Nahlik,

643 Mitsch, 2010; Hendriks et al. 2007; Herbst et al., 2013; Wilson et al. 2016). We assume that

644 during wetter years $\mathrm{CH}_{4}$ emissions at the restored sites would be similar to those that have

645 been measured from these undrained sites (Leppälä et al 2011c). This is supported by

646 similarities in the vegetation composition and WT dynamics between our undrained and

647 restored sites. In addition, there are indications that at our sites the soil microbial community,

648 both methanogens and methanotrophs, was recovering rapidly after restoration (Putkinen et

649 al. 2012).

650

651 Warming increased $\mathrm{CH}_{4}$ fluxes, but only at the undrained sites. Both microbial methane

652 production and oxidation are dependent on temperature (Dunfield et al. 1993), and the

653 existing studies on warming impacts are inconclusive. Turetsky et al. (2008) found increased

654 and Peltoniemi et al. (2016) decreased methane emissions in fens, while some other studies

655 have found no impact (Johnson et al. 2013; Pearson et al. 2015). The warming impact is

656 likely dependent on moisture conditions as in water-saturated conditions emissions have

657 increased, while the opposite has been observed from drier hummocks (Munir, Strack 2014;

658 Gill et al. 2017). This is partly in accordance with our study, as the water table was generally

659 higher in undrained than in drained sites. Why $\mathrm{CH}_{4}$ fluxes at the restored sites did not 
respond similarly to warming remains an unanswered question, however, as the restored and

661 undrained water tables were similar, and Putkinen et al. (2012) showed that the methanogen

662 community was not poorly developed and therefore would be able to respond to warming.

663

664

\subsection{Nitrous oxide}

665 Nitrous oxide plays a minor role in the GHG dynamics of these primary mires. We measured

666 higher $\mathrm{N}_{2} \mathrm{O}$ fluxes from drained sites than from undrained sites, which is typical especially in

667 fen mires (Regina et al. 1996; Ojanen et al. 2010; Pearson et al. 2015). The flux rates were

668 within the range measured from other Finnish forestry drained mires (Ojanen et al. 2010). We

669 observed modest seasonal variability in the flux rates and were not able to explain the fluxes

670 with environmental variables, although temperate and moisture conditions are generally seen

671 as regulators of seasonal flux variability (Kitzler et al. 2006). The experimental warming

672 seemed to increase the $\mathrm{N}_{2} \mathrm{O}$ fluxes, likely due to high temperature sensitivity of

673 denitrification and consequently $\mathrm{N}_{2} \mathrm{O}$ fluxes (Butterbach-Bahl et al. 2013). Our finding is in

674 contrast to earlier studies from pristine mires (Ward et al. 2013, Pearson et al. 2015), but the

675 disparity may be explained by differences in moisture conditions and other site characteristics

676 as they may restrain the stimulating effect of temperature (Butterbach-Bahl, Dannenmann

677 2011). Our data set on $\mathrm{N}_{2} \mathrm{O}$ is however, limited to five measurement campaigns, and do to a

678 sporadic nature of $\mathrm{N}_{2} \mathrm{O}$ emissions (Butterbach-Bahl et al. 2013) we would not draw any

679 strong conclusions from this result.

680

681

\section{Conclusions}

682 In our study, restoration appeared to be an effective climate mitigation tool; restoration quickly returned the ecosystem functions of undrained primary mires and reversed unwanted 
impacts of drainage, such as high respiration rates. The global warming potential (GWP)

685

686

687

688

689

690

691

692

693

694

695

696

697

698

699

700

701

702

703

704

705

706

707 varied largely between sites and years, and most sites, including the undrained ones, had a positive GWP, especially during the dry year 2013. It seems that restoration of boreal forestry drained mires is relatively fast and easy task compared to mires drained for agricultural purposes (Klimkowska et al. 2007) or peat harvesting areas (Chimner at al. 2017). A likely reason is that forestry drainage causes less disturbance to vegetation cover and soil. These differences should be further evaluated. In restored, as well as other sites, warming accelerated net ecosystem $\mathrm{CO}_{2}$ sink function, due to increased LAI and we did not see any signs that moderate warming would compromise the climate mitigation of restoration.

\section{Acknowledgements}

We acknowledge funding from the University of Helsinki and Kone foundation (A. M. Laine), the Natural Resources Institute Finland (A. Tolvanen), the Fulbright-Finland and Saastamoinen Foundations (S. Frolking), and the Academy of Finland (project code 287039) (E.-S. Tuittila). We thank Ivka Vasil`ka, Annukka Närhi and Mirkka Kotiaho for field assistance.

\section{Data Statement}

The datasets generated during and/or analysed during the current study are available from the corresponding author on request.

\section{Supplementary material for online publication:}

Supporting information 1. Nonlinear mixed-effect model based on leaf area index Supporting information 2. Nonlinear mixed-effect model based on $\mathrm{CO}_{2}$ flux measurements

Supporting information 3. Linear mixed effect models based on $\mathrm{CH}_{4}$ measurements 
708 Supporting information 4. Linear mixed effect models based on $\mathrm{N}_{2} \mathrm{O}$ measurements 709

710 
712 Aichi Biodiversity Targets. 2011. Convention on Biological Diversity, 2011. Strategic Plan

713 for Biodiversity 2011-2020. Available at http://www.cbd.int/sp/targets/. (accessed $16^{\text {th }}$

714 January 2018).

715 Alm, J., Schulman, L., Walden, J., Nykänen, H., Martikainen, P. J. Silvola, J., 1999. Carbon

716 balance of a boreal bog during a year with an exceptionally dry summer. Ecology 80, 161$717 \quad 174$.

718 Alm, J., Shurpali, N. J., Tuittila, E. S., Laurila, T., Maljanen, M., Saarnio, S., Minkkinen, K., 719 2007. Methods for determining emission factors for the use of peat and peatlands flux

720 measurements and modelling. Boreal Environ. Res. 12, 85-100.

721 Aurela, M., Lohila, A., Tuovinen, J. P., Hatakka, J., Riutta, T., Laurila, T,. 2009. Carbon

722 dioxide exchange on a northern boreal fen. Boreal Environ. Res. 14, 699-710.

723 Badorek, T., Tuittila, E. S., Ojanen, P., Minkkinen, K., 2011. Forest floor photosynthesis and 724 respiration in a drained peatland forest in southern Finland. Plant Ecology, Diversity 4(2-3), $725 \quad 227-241$.

726 Barr, A. G., Black, T. A., Hogg, E. H., Kljun, N., Morgenstern, K., Nesic, Z., 2004. Inter727 annual variability in the leaf area index of a boreal aspen-hazelnut forest in relation to net 728 ecosystem production. Agricultural and Forest Meteorology 126(3), 237-255.

729 Bonn, A., Reed, M. S., Evans, C. D., Joosten, H., Bain, C., Farmer, J., Emmer, I., 730 Couwenberg, J., Moxey, A., Artz, R., Tanneberger, F., von Unger, M., Smyth, M.-A., Birnie, 731 D., 2014. Investing in nature, developing ecosystem service markets for peatland restoration.

732 Ecosystem Services 9, 54-65. 
733 Bubier, J. L., Moore, T. R., Roulet, N. T., 1993. Methane emissions from wetlands in the

734 midboreal region of northern Ontario, Canada. Ecology 74(8), 2240-2254.

735 Butterbach-Bahl, K., Dannenmann, M., 2011. Denitrification and associated soil N2O

736 emissions due to agricultural activities in a changing climate. Current Opinion in

737 Environmental Sustainability 3(5), 389-395.

738 Butterbach-Bahl, K., Baggs, E. M., Dannenmann, M., Kiese, R., Zechmeister-Boltenstern, S., 739 2013. Nitrous oxide emissions from soils: how well do we understand the processes and their 740 controls?. Phil. Trans. R. Soc. B. 368(1621), 20130122.

741 Buttler, A., Robroek, B. J.M., Laggoun-Défarge, F., Jassey, V. E.J., Pochelon, C., Bernard,

742 G., Delarue, F., Gogo, S., Mariotte, P., Mitchell, E. A.D. Bragazza, L., 2015. Experimental

743 warming interacts with soil moisture to discriminate plant responses in an ombrotrophic 744 peatland. Journal of Vegetation Science 26, 964-974.

745 Chimner, R. A., Cooper, D. J., Wurster, F. C., Rochefort, L., 2017. An overview of peatland 746 restoration in North America: where are we after 25 years?. Restoration Ecology 25(2), 283747292.

748 Chivers, M. R., Turetsky, M. R., Waddington, J. M., Harden, J. W., McGuire, A. D., 2009.

749 Effects of experimental water table and temperature manipulations on ecosystem $\mathrm{CO}_{2}$ fluxes 750 in an Alaskan rich fen. Ecosystems 12(8), 1329-1342.

751 Christensen, T. R., Jackowicz-Korczyński, M., Aurela, M., Crill, P., Heliasz, M.,

752 Mastepanov, M., Friborg, T., 2012. Monitoring the multi-year carbon balance of a subarctic 753 palsa mire with micrometeorological techniques. Ambio 41(3), 207-217.

754 Cornelius, C., Heinichen, J., Drösler, M., Menzel, A., 2014. Impacts of temperature and water 755 table manipulation on grassland phenology. Applied Vegetation Science 17(4), 625-635. 
Dorrepaal, E., Toet, S., van Logtestijn, R. S., Swart, E., van de Weg, M. J., Callaghan, T. V.,

757

758

759

760

761

762

763

764

765

766

767

768

769

770

771

772

773

774

775

776

777

778

779

Aerts, R., 2009. Carbon respiration from subsurface peat accelerated by climate warming in the subarctic. Nature 460(7255), 616-619.

Dunfield, P., Dumont, R., Moore, T. R., 1993. Methane production and consumption in temperate and subarctic peat soils, response to temperature and $\mathrm{pH}$. Soil Biology and Biochemistry 25(3), 321-326.

Ekman, M., 1996. A consistent map of the postglacial uplift of Fennoscandia. Terra Nova $8(2), 158-165$.

Elmendorf, S. C., Henry, G. H. R., Hollister, R. D., Björk, R. G., Bjorkman, A. D., Callaghan, T. V., Collier, L. S., Cooper, E. J., Cornelissen, J. H. C., Day, T. A., Fosaa, A. M., Gould, W. A., Grétarsdóttir, J., Harte, J., Hermanutz, L., Hik, D. S., Hofgaard, A., Jarrad, F., Jónsdóttir, I. S., Keuper, F., Klanderud, K., Klein, J. A., Koh, S., Kudo, G., Lang, S. I., Loewen, V., May, J. L., Mercado, J., Michelsen, A., Molau, U., Myers-Smith, I. H., Oberbauer, S. F., Pieper, S., Post, E., Rixen, C., Robinson, C. H., Schmidt, N. M., Shaver, G. R., Stenström, A., Tolvanen, A., Totland, Ø., Troxler, T., Wahren, C.-H., Webber, P. J., Welker, J. M., Wookey, P. A., 2012, Global assessment of experimental climate warming on tundra vegetation: heterogeneity over space and time. Ecology Letters 15: 164-175. EU Biodiversity Strategy to 2020, European Commission, 2012. EU Biodiversity Strategy to 2020. Available at http:// ec.europa.eu/environment/nature/biodiversity/comm2006/ 2020.htm. (accessed 16 January 2018).

Frolking, S., Roulet, N. T., 2007. Holocene radiative forcing impact of northern peatland carbon accumulation and methane emissions. Global Change Biology 13(5), 1079-1088. Frolking, S., Talbot, J., Jones, M. C., Treat, C. C., Kauffman, J. B., Tuittila, E. S., Roulet, N., 2011. Peatlands in the Earth's 21st century climate system. Environ. Rev. 19, 371-396. 
Garnet, K. N., Megonigal, J. P., Litchfield, C., Taylor, G. E., 2005. Physiological control of leaf methane emission from wetland plants. Aquatic Botany 81(2), 141-155.

782

Gill, A. L., Giasson, M. A., Yu, R., Finzi, A. C., 2017. Deep peat warming increases surface methane and carbon dioxide emissions in a black spruce dominated ombrotrophic bog.

784 Global Change Biology 23: 5398-5411.

785 Graf, M. D., Rochefort, L., Poulin, M., 2008. Spontaneous revegetation of cutwaway peatlands of North America. Wetlands 28(1), 28-39.

787 Harrell Jr, F. E., 2001. Regression modeling strategies, with applications to linear models, 788 logistic and ordinal regression, and survival analysis. Springer New York.

789 Heinonen, J., 1994. KPL-koealojen puu-ja puustotunnusten laskentaohjelman käyttöohje. (A 790 guide to calculate tree- and treestand parameters of KPL-sample plots.) (in Finnish). The 791 Finnish Forest Research Institute Research Papers 504, 1-80.

792 Helfter, C., Campbell, C., Dinsmore, K. J., Drewer, J., Coyle, M., Anderson, M., Skiba, U., 793 Nemitz, E., Billett, M. F., Sutton, M. A., 2015. Drivers of long-term variability in $\mathrm{CO}_{2}$ net 794 ecosystem exchange in a temperate peatland. Biogeosciences 12(6), 1799-1811.

795 Hellemaa, P., 1998. The development of coastal dunes and their vegetation in Finland. Fennia 796 - International Journal of Geography 176, 111-221.

797 Hendriks, D. M. D., Van Huissteden, J., Dolman, A. J., Van der Molen, M. K., 2007. The full 798 greenhouse gas balance of an abandoned peat meadow. Biogeosciences Discussions 4(1), $799 \quad 277-316$.

800 Herbst, M., Friborg, T., Schelde, K., Jensen, R., Ringgaard, R., Vasquez, V., Thomsen, A. G., 801 Søgaard, H., 2013. Climate and site management as driving factors for the atmospheric 802 greenhouse gas exchange of a restored wetland. Biogeosciences 10(1), 39-52. 
Hobbs, R. J., Cramer, V. A., 2008. Restoration ecology: interventionist approaches for restoring and maintaining ecosystem function in the face of rapid environmental change. Annu. Rev. Environ. Resour. 33, 39-61. Hommeltenberg, J., Schmid, H. P., Drösler, M., Werle, P., 2014. Can a bog drained for

807 forestry be a stronger carbon sink than a natural bog forest?. Biogeosciences 11(13), 34778083493.

809 Intergovernmental Panel on Climate Change (IPCC), 2013. Climate Change 2013: The

810 Physical Science Basis. Contribution of Working Group I to the Fifth Assessment Report of

811 the Intergovernmental Panel on Climate Change [Stocker, T.F., D. Qin, G.-K. Plattner, M.

812 Tignor, S.K. Allen, J. Boschung, A. Nauels, Y. Xia, V. Bex, P.M. Midgley (eds.)].

813 Cambridge University Press, Cambridge, United Kingdom and New York, NY, USA.

814 Jauhiainen, J., Page, S. E., Vasander, H., 2016. Greenhouse gas dynamics in degraded and 815 restored tropical peatlands. Mires and Peat 17, 1-12.

816 Johnson, C. P., Pypker, T. G., Hribljan, J. A., Chimner, R. A., 2013. Open top chambers and

817 infrared lamps, A comparison of heating efficacy and $\mathrm{CO}_{2} / \mathrm{CH}_{4}$ dynamics in a northern

818 Michigan peatland. Ecosystems 16(5), 736-748.

819 Joosten, H., Tannenberger, F., Moen, A. 2017. Mires and peatlands of Europe..

820 Schweizerbart Science Publishers, Stuttgart, Germany, p. 780.

821 Joosten, $\mathrm{H} ., 2010$. The global peatland $\mathrm{CO}_{2}$ picture: peatland status and drainage related 822 emissions in all countries in the world. Report for Wetlands International, Wageningen, The 823 Netherlands.

824 Kareksela, S., Haapalehto, T., Juutinen, R., Matilainen, R., Tahvanainen, T., Kotiaho, J. S., 825 2015. Fighting carbon loss of degraded peatlands by jump-starting ecosystem functioning 826 with ecological restoration. Science of the Total Environment 537, 268-276. 
827 Kitzler, B., Zechmeister-Boltenstern, S., Holtermann, C., Skiba, U., Butterbach-Bahl, K., 828 2006. Nitrogen oxides emission from two beech forests subjected to different nitrogen loads.

829 Biogeosciences 3(3), 293-310.

830 Klimkowska, A., Van Diggelen, R., Bakker, J. P., Grootjans, A. P., 2007. Wet meadow

831 restoration in Western Europe: a quantitative assessment of the effectiveness of several

832 techniques. Biological Conservation 140(3-4), 318-328.

833 Knox, S. H., Sturtevant, C., Matthes, J. H., Koteen, L., Verfaillie, J., aldocchi, D., 2015.

834 Agricultural peatland restoration, effects of land-use change on greenhouse gas $\left(\mathrm{CO}_{2}\right.$ and

$835 \mathrm{CH}_{4}$ ) fluxes in the Sacramento-San Joaquin Delta. Global Change Biology 21(2), 750-765.

836 Komulainen, V. M., Nykänen, H., Martikainen, P. J., Laine, J., 1998. Short-term effect of

837 restoration on vegetation change and methane emissions from peatlands drained for forestry

838 in southern Finland. Canadian Journal of Forest Research 28(3), 402-411

839 Komulainen, V. M., Tuittila, E. S., Vasander, H., Laine, J., 1999. Restoration of drained

840 peatlands in southern Finland, initial effects on vegetation change and $\mathrm{CO}_{2}$ balance. Journal 841 of Applied Ecology 36(5), 634-648.

842 Korrensalo, A., Hájek, T., Vesala, T., Mehtätalo, L., Tuittila, E. S., 2016. Variation in 843 photosynthetic properties among bog plants. Botany 94(12), 1127-1139.

844 Koskinen, M., Maanavilja, L., Nieminen, M., Minkkinen, K., Tuittila, E. S., 2016. High

845 methane emissions from restored Norway spruce swamps in southern Finland over one 846 growing season. Mires and Peat 17, 1-13.

847 Kudernatsch, T., Fischer, A., Bernhardt-Römermann, M., Abs, C., 2008. Short-term effects of 848 temperature enhancement on growth and reproduction of alpine grassland species. Basic and 849 Applied Ecology 9(3), 263-274. 
850 Lafleur, P. M., Moore, T. R., Roulet, N. T., Frolking, S., 2005. Ecosystem respiration in a

851 cool temperate bog depends on peat temperature but not water table. Ecosystems 8(6), 619-

852629

853 Lai, D. Y. F., 2009. Methane dynamics in northern peatlands, a review. Pedosphere 19(4),

$854 \quad 409-421$.

855 Laiho, R., Laine, J., 1997. Tree stand biomass and carbon content in an age sequence of

856 drained pine mires in southern Finland. Forest Ecology and Management 93(1-2), 161-169.

857 Laine, A. M., Tolvanen, A., Mehtätalo, L., Tuittila, E. S., 2016. Vegetation structure and 858 photosynthesis respond rapidly to restoration in young coastal fens. Ecology and Evolution, 859 6(19), 6880-6891.

860 Laine, J., Vasander, H., Laiho, R., 1995. Long-term effects of water level drawdown on the

861 vegetation of drained pine mires in southern Finland. Journal of Applied Ecology 32, 785-

862802.

863 Laitinen, J., Rehell, S., Oksanen, J., 2008. Community and species responses to water level

864 fluctuations with reference to soil layers in different habitats of mid-boreal mire complexes.

865 Plant Ecology 194(1), 17-36.

866 Lappi, J.,Oker-Blom, P. 1992. Characterizing photosynthetic radiation response or other

867 output function as a mean of element responses. J. Theor. Biol. 154, 371-389.

868 Leppälä, M., Laine, A. M., Seväkivi, M. L., Tuittila, E. S., 2011a. Differences in $\mathrm{CO}_{2}$

869 dynamics between successional mire plant communities during wet and dry summers. Journal

870 of Vegetation Science 22(2), 357-366.

871 Leppälä, M., Laine, A., Tuittila, E. S., 2011b. Winter carbon losses from a boreal mire

872 succession sequence follow summertime patterns in carbon dynamics. Suo 62(1), 1-11.

873 Leppälä, M., Oksanen, J., Tuittila, E. S., 2011c. Methane flux dynamics during mire

874 succession. Oecologia 165(2), 489-499. 
875 Lohila, A., Minkkinen, K., Aurela, M., Tuovinen, J. P., Penttilä, T., Ojanen, P., Laurila, T., 876 2011. Greenhouse gas flux measurements in a forestry-drained peatland indicate a large 877 carbon sink. Biogeosciences 8(11), 3203-3218.

878 Lund, M., Christensen, T. R., Lindroth, A., Schubert, P., 2012. Effects of drought conditions 879 on the carbon dioxide dynamics in a temperate peatland. Environmental Research Letters $8807(4), 045704$.

881 Lund, M., Lafleur, P. M., Roulet, N. T., Lindroth, A., Christensen, T. R., Aurela, M., 882 Chojnicki, B. H., Flanagan, L. B., Humphreys, E. R., Laurila, T., Oechel, W. C., Olejnik, J., 883 Rinne, J., Schubert, P., Nilsson, M. B., 2010. Variability in exchange of $\mathrm{CO}_{2}$ across 12 884 northern peatland and tundra sites. Global Change Biology 16(9), 2436-2448.

885 Luoma, S., 1997. Geographical pattern in photosynthetic light response of Pinus sylvestris in 886 Europe. Functional Ecology 11(3), 273-281.

887 Maljanen, M., Sigurdsson, B. D., Guðmundsson, J., Óskarsson, H., Huttunen, J. T., 888 Martikainen, P. J., 2010. Greenhouse gas balances of managed peatlands in the Nordic 889 countries-present knowledge and gaps. Biogeosciences 7(9), 2711-2738.

890 Martikainen, P. J., Nykänen, H., Alm, J., Silvola, J., 1995. Change in fluxes of carbon 891 dioxide, methane and nitrous oxide due to forest drainage of mire sites of different trophy. In 892 Nutrient Uptake and Cycling in Forest Ecosystems (pp. 571-577). Springer Netherlands. 893 McVeigh, P., Sottocornola, M., Foley, N., Leahy, P., Kiely, G., 2014. Meteorological and 894 functional response partitioning to explain interannual variability of $\mathrm{CO}_{2}$ exchange at an Irish 895 Atlantic blanket bog. Agricultural and Forest Meteorology 194, 8-19.

896 Medlyn, B. E., Dreyer, E., Ellsworth, D., Forstreuter, M., Harley, P. C., Kirschbaum, M. U.

897 F., Le Roux, X., Montpied, P., Strassemeyer, J., Walcroft, A., Wang, K. Loustau, D., 2002.

898 Temperature response of parameters of a biochemically based model of photosynthesis. II. A 899 review of experimental data. Plant, Cell, Environment 25(9), 1167-1179. 
901 of climate change on wetland ecosystems and carbon dynamics. Environmental Research

902

903

904

905

906

907

908

909

910

911

912

913

914

915

916

917

918

919

920

921

922

923

924

Letters 11(10), 100201.

Merilä, P., Galand, P. E., Fritze, H., Tuittila, E. S., Kukko-oja, K., Laine J., Yrjälä K., 2006.

Methanogen communities along a primary succession transect of mire ecosystems. FEMS

Microbiol. Ecol. 55, 221-229.

Miettinen, J., Shi, C., Liew, S. C., 2016. Land cover distribution in the peatlands of Peninsular Malaysia, Sumatra and Borneo in 2015 with changes since 1990. Global Ecology and Conservation 6, 67-78.

Minkkinen, K., Ojanen, P., Penttilä, T., Aurela, M., Laurila, T., Tuovinen, J.-P., Lohila, A., (2018, in review). Carbon accumulation in a drained boreal bog was decreased but not stopped by seasonal drought, Biogeosciences Discuss., https://doi.org/10.5194/bg-2017-530.

Minkkinen, K., Laine, J., Shurpali, N. J., Mäkiranta, P., Alm, J., Penttilä, T., 2007.

Heterotrophic soil respiration in forestry-drained peatlands. Boreal Environmental Research $12,115-126$

Minkkinen, K., Vasander, H., Jauhiainen, S., Karsisto, M., Laine, J., 1999. Post-drainage changes in vegetation composition and carbon balance in Lakkasuo mire, Central Finland. Plant and Soil 207(1), 107-120.

Moore, T. R., Dalva, M., 1993. The influence of temperature and water table position on carbon dioxide and methane emissions from laboratory columns of peatland soils. Journal of Soil Science 44(4), 651-664.

Munir, T. M., Strack, M., 2014. Methane flux influenced by experimental water table drawdown and soil warming in a dry boreal continental bog. Ecosystems 17(7), 1271-1285

Myhre, G., D. Shindell, F.-M. Bréon, W., Collins, J., Fuglestvedt, J., Huang, D., Koch, J.-F. Lamarque, D., Lee, B., Mendoza, T., Nakajima, A., Robock, G., Stephens, T. Takemura, H. 
925 Zhang., 2013. Anthropogenic and Natural Radiative Forcing. In: Climate Change 2013: The 926 Physical Science Basis. Stocker, T.F., D. Qin, G.-K. Plattner, M., Tignor, S.K., Allen, J., 927 Boschung, A., Nauels, Y., Xia, V. Bex and P.M. Midgley (eds.), Contribution of Working 928 Group I to the Fifth Assessment Report of the Intergovernmental Panel on Climate Change.

929 Cambridge University Press Cambridge, United Kingdom and New York, NY, USA

930 Mäkiranta, P., Laiho, R., Fritze, H., Hytönen, J., Laine, J., Minkkinen, K., 2009. Indirect 931 regulation of heterotrophic peat soil respiration by water level via microbial community 932 structure and temperature sensitivity. Soil Biology and Biochemistry 41(4), 695-703.

933 Mäkiranta, P., Laiho, R., Mehtätalo, L., Straková, P., Sormunen, J., Minkkinen, K., Penttilä,

934 T., Fritze, H., Tuittila, E.-S., 2018. Responses of phenology and biomass production of boreal 935 fens to climate warming under different water-table level regimes. Global Change Biology $936 \quad 24,944-956$.

937 Mälson, K., Backéus, I., Rydin, H., 2007. Long-term effects of drainage and initial effects of 938 hydrological restoration on rich fen vegetation. Applied Vegetation Science 11(1), 99-106.

939 Nahlik, A. M., Mitsch, W. J., 2010. Methane emissions from created riverine wetlands.

940 Wetlands 30(4), 783-793.

941 Nilsson, M., Sagerfors, J., Buffam, I., Laudon, H., Eriksson, T., Grelle, A., Klemedtsson, L., 942 Weslien, P., Lindroth, A., 2008, Contemporary carbon accumulation in a boreal oligotrophic 943 minerogenic mire - a significant sink after accounting for all C-fluxes. Global Change

944 Biology 14, 2317-2332.

945 Ojanen, P., Minkkinen, K., Penttilä, T., 2013. The current greenhouse gas impact of forestry946 drained boreal peatlands. Forest Ecology and Management 289, 201-208.

947 Ojanen, P., Minkkinen, K., Alm, J., Penttilä, T., 2010. Soil-atmosphere $\mathrm{CO}_{2}, \mathrm{CH}_{4}$ and $\mathrm{N}_{2} \mathrm{O}$ 948 fluxes in boreal forestry-drained peatlands. Forest Ecology and Management 260(3), 411949421. 
950 Paavilainen, E., Päivänen, J., 1995. Peatland forestry, ecology and principles (Vol. 111) (250

951 pp). Springer Science, Business Media.

952 Parviainen, T., 1999. Sekametsikön koivujen biomassan ja latvusrakenteen selvittäminen

953 elintoimintoihin perustuvia kasvumalleja varten (Determining birch biomass and crown

954 structure in mixed forests to be used with growth models based in vital functions), MSc

955 Thesis. Department of Forest Ecology, University of Helsinki, Finland. (in Finnish.)

956 Pearson, M., Penttilä, T., Harjunpää, L., Laiho, R., Laine, J., Sarjala, T., Silvan, K.,Silvan, N.,

957 2015. Effects of temperature rise and water-table-level drawdown on greenhouse gas fluxes

958 of boreal sedge fens. Boreal Environment Research 20(4), 489-505.

959 Peichl, M., Öquist, M., Löfvenius, M. O., Ilstedt, U., Sagerfors, J., Grelle, A., Lindroth,

960 A.,Nilsson, M. B., 2014. A 12-year record reveals pre-growing season temperature and water

961 table level threshold effects on the net carbon dioxide exchange in a boreal fen.

962 Environmental Research Letters 9(5), 055006.

963 Pelletier, L., Moore, T. R., Roulet, N. T., Garneau, M., Beaulieu-Audy, V., 2007. Methane

964 fluxes from three peatlands in the La Grande Riviere watershed, James Bay lowland, Canada.

965 Journal of Geophysical Research, Biogeosciences 112(G1).

966 Peltoniemi, K., Laiho, R., Juottonen, H., Bodrossy, L., Kell, D. K., Minkkinen, K.,

967 Mäkiranta, P., Mehtätalo, L., Penttilä, T., Siljanen, H. M.P., Tuittila, E. S. Tuomivirta, T.,

968 Fritze, H., 2016. Responses of methanogenic and methanotrophic communities to warming in

969 varying moisture regimes of two boreal fens. Soil Biology and Biochemistry 97, 144-156.

970 Pinheiro, J. C., Bates D. M., 2000. Mixed-effects models in S and S-plus. Springer-Verlag, 971 New York. 
972 Pirinen, P., Simola, H., Aalto, J., Kaukoranta, J. P., Karlsson, P., Ruuhela, R., 2012. Tilastoja 973 suomen ilmastosta 1981-2010. (Climatological statistics of Finland 1981-2010). (in Finnish), 974 Ilmatieteen laitos (Finnish Meteorological Institute), Helsinki.

975 Putkinen, A., Juottonen, H., Tuittila, E.-S., Peltoniemi, K., Tolvanen, A., Tuomivirta, T., 976 Yrjälä, K., Fritze, H., 2012. Methane turnover before and after restoration of young forestry977 drained fens. In, Magnusson, T (ed.) Peatlands in Balance Book of Abstracts of the 14th 978 International Peat Congress.

979 Regina, K., Nykänen, H., Silvola, J., Martikainen, P. J., 1996. Fluxes of nitrous oxide from 980 boreal peatlands as affected by peatland type, water table level and nitrification capacity. 981 Biogeochemistry 35(3), 401-418.

982 Renou-Wilson, F., Barry, C., Müller, C., Wilson, D., 2014. The impacts of drainage, nutrient 983 status and management practice on the full carbon balance of grasslands on organic soils in a 984 maritime temperate zone. Biogeosciences 11(16), 4361-4379.

985 Repola, J., 2008. Biomass equations for birch in Finland. Silva Fennica 42(4), 605-624.

986 Repola, J. 2009. Biomass equations for Scots pine and Norway spruce in Finland. Silva 987 Fennica 43(4), 625-647.

988 Rinne, J., Riutta, T., Pihlatie, M., Aurela, M., Haapanala, S., Tuovinen, J. P., Tuittila, E.-S., 989 Vesala, T., 2007. Annual cycle of methane emission from a boreal fen measured by the eddy 990 covariance technique. Tellus B 59(3), 449-457.

991 Roulet, N. T., Moore, T. R., 1995. The effect of forestry drainage practices on the emission of 992 methane from northern peatlands. Canadian Journal of Forest Research 25(3), 491-499.

993 Roulet, N. T., Lafleur, P. M., Richard, P. J., Moore, T. R., Humphreys, E. R., Bubier, J., 994 2007. Contemporary carbon balance and late Holocene carbon accumulation in a northern 995 peatland. Global Change Biology 13(2), 397-411. 
996 Silvola, J., Alm, J., Ahlholm, U., Nykanen, H., Martikainen, P. J., 1996. CO 2 fluxes from peat

997 in boreal mires under varying temperature and moisture conditions. Journal of Ecology 84, $998 \quad 219-228$.

999 Strack, M., Zuback, Y. C. A., 2013. Annual carbon balance of a peatland $10 \mathrm{yr}$ following 1000 restoration. Biogeosciences 10(5), 2885-2896.

1001 Ström, L., Ekberg, A., Mastepanov, M., Christensen, R. T., 2003. The effect of vascular 1002 plants on carbon turnover and methane emissions from a tundra wetland. Global Change 1003 Biology 9(8), 1185-1192.

1004 Suyker, A. E., Verma, S. B., Clement, R. J., Billesbach, D. P., 1996. Methane flux in a boreal 1005 fen, Season-long measurement by eddy correlation. Journal of Geophysical Research, 1006 Atmospheres 101(D22), 28637-28647.

1007 Tarvainen, O., Laine, A. M., Peltonen, M., Tolvanen, A., 2013. Mineralization and 1008 decomposition rates in restored pine fens. Restoration Ecology 21(5), 592-599.

1009 Trudeau, N. C., Garneau, M., Pelletier, L., 2013. Methane fluxes from a patterned fen of the 1010 northeastern part of the La Grande river watershed, James Bay, Canada. Biogeochemistry $1011 \quad 113(1-3), 409-422$.

1012 Tuittila E-S., Juutinen S., Frolking S., Väliranta M., Laine A., Miettinen A., Quillet A., 1013 Merilä P., 2013. Wetland chronosequence as a model of peatland development: Vegetation 1014 succession, peat and carbon accumulation. The Holocene 23: 23-33.

1015 Tuittila, E. S., Komulainen, V. M., Vasander, H., Laine, J., 1999. Restored cut-away peatland 1016 as a sink for atmospheric $\mathrm{CO}_{2}$. Oecologia 120(4), 563-574.

1017 Tuittila, E.-S., Komulainen, V.-M., Vasander, H., Nykänen, H., Martikainen, P. J., Laine, J., 1018 2000. Methane dynamics of a restored cut-away peatland. Global Change Biology 6, 5691019581. 
1020 Tuittila, E-S., Vasander, H., Laine, J., 2000. Impact of rewetting on the vegetation of a cut1021 away peatland. Applied Vegetation Science 3, 205-212.

1022 Turetsky, M. R., Treat, C. C., Waldrop, M. P., Waddington, J. M., Harden, J. W., McGuire,

1023 A. D., 2008. Short-term response of methane fluxes and methanogen activity to water table

1024 and soil warming manipulations in an Alaskan peatland. Journal of Geophysical Research,

1025 Biogeosciences 113(G3).

1026 Urbanová, Z., Picek, T., Hájek, T., Bufková, I., Tuittila, E. S., 2012. Vegetation and carbon

1027 gas dynamics under a changed hydrological regime in central European peatlands. Plant

1028 Ecology, Diversity 5(1), 89-103.

1029 Waddington, J. M., Strack, M., Greenwood, M. J., 2010. Toward restoring the net carbon sink 1030 function of degraded peatlands, Short-term response in $\mathrm{CO}_{2}$ exchange to ecosystem-scale

1031 restoration. Journal of Geophysical Research, Biogeosciences 115(G1).

1032 Voigt, C., Lamprecht, R. E., Marushchak, M. E., Lind, S. E., Novakovskiy, A., Aurela, M., 1033 Martikainen, P. J., Biasi, C., 2017. Warming of subarctic tundra increases emissions of all 1034 three important greenhouse gases-carbon dioxide, methane, and nitrous oxide. Global 1035 Change Biology 23(8), 3121-3138.

1036 Ward, S. E., Ostle, N. J., Oakley, S., Quirk, H., Henrys, P. A., Bardgett, R. D., 2013.

1037 Warming effects on greenhouse gas fluxes in peatlands are modulated by vegetation

1038 composition. Ecology Letters 16(10), 1285-1293.

1039 Weltzin, J. F., Bridgham, S. D., Pastor, J., Chen, J., Harth, C., 2003. Potential effects of 1040 warming and drying on peatland plant community composition. Global Change Biology 9(2), $1041 \quad 141-151$.

1042 Wiedermann, M. M., Nordin, A., Gunnarsson, U., Nilsson, M. B., Ericson, L., 2007. Global 1043 change shifts vegetation and plant-parasite interactions in a boreal mire. Ecology 88(2), 4541044464. 
1045 Wilson, D., Alm, J., Riutta, T., Laine, J., Byrne, K. A., Farrell, E. P., Tuittila, E. S., 2007. A

1046 high resolution green area index for modelling the seasonal dynamics of $\mathrm{CO}_{2}$ exchange in

1047 peatland vascular plant communities. Plant Ecology 190(1), 37-51.

1048 Wilson, D., Farrell, C. A., Fallon, D., Moser, G., Müller, C., Renou-Wilson, F., 2016.

1049 Multiyear greenhouse gas balances at a rewetted temperate peatland. Global Change Biology

$1050 \quad 22,4080-4095$

1051 Wilson, J. W., 1959. Analysis of the spatial distribution of foliage by two-dimensional point 1052 quadrats. New Phytologist 58(1), 92-99.

1053 Vompersky, S. E., Sirin, A. A., 1997. Hydrology of drained forested wetlands. in Trettin, C.

1054 C., Jurgense, M. F., Grigal, D. F., Gale, M. R., Jeglum, J. K. eds. Northern forested wetlands.

1055 Ecology and management. CRS Press Inc., Lewish Publishers, Boca Raton, FL. pp. 189-211.

1056 Yu, Z., Beilman, D. W., Frolking, S., MacDonald, G. M., Roulet, N. T., Camill, P., Charman,

1057 D. J., 2011. Peatlands and Their Role in the Global Carbon Cycle. Eos Trans. AGU 92(12), 105897.

1059 Yu, Z. C., 2012. Northern peatland carbon stocks and dynamics: a review. Biogeosciences $10609(10), 4071-4085$. 
1062 Table 1. Average air and soil temperature $\left({ }^{\circ} \mathrm{C}\right)$ at OTC warming plots and ambient-T plots in

1063 Undrained, Restored and Drained land use category during spring (May), summer (June-

1064 August) and autumn (September-November). Statistically significant $(\mathrm{p}<0.05)$ differences

1065 between OTC and Ambient-T plots are marked with * (ANOVA-tests).

\begin{tabular}{ll|cc|cc|cc}
\hline & & \multicolumn{2}{|c|}{ Spring } & \multicolumn{2}{c|}{ Summer } & \multicolumn{2}{c}{ Autumn } \\
& & OTC & Ambient-T & OTC & Ambient-T & OTC & Ambient-T \\
\hline Air T at & Undrained & 18.9 & $16.8^{*}$ & 17.1 & $15.8^{*}$ & 7.4 & $6.5^{*}$ \\
$15 \mathrm{~cm}$ & Restored & 18.7 & 17.7 & 17.0 & $16.3^{*}$ & 7.8 & $7.1^{*}$ \\
& Drained & 17.0 & 16.3 & 15.9 & 15.3 & 7.3 & 6.9 \\
\multirow{2}{*}{ Soil T at } & Undrained & 11.4 & 11.4 & 14.9 & 14.6 & 9.1 & 8.3 \\
& Restored & 11.5 & 10.8 & 12.5 & 12.7 & 9.4 & 9.7 \\
& Drained & 8.3 & 8.2 & 12.5 & 12.7 & 8.7 & 8.5 \\
\hline
\end{tabular}

1066

1067 
1068 Table 2. Average annual and summer time temperature (T) and precipitation (Prec) in study 1069 years 2011 and 2013, and the long-term averages for period 1981-2010. Summer denotes for

1070 June-August. Data from Siikajoki, Revonlahti weather station, Finnish Meteorological

1071 Institute and from Pirinen et al. 2012.

\begin{tabular}{ccccc}
\hline Period & T year, ${ }^{\circ} \mathrm{C}$ & T summer, ${ }^{\circ} \mathrm{C}$ & Prec year, mm & Prec summer, mm \\
\hline 2011 & 4.3 & 16.0 & 570 & 203 \\
2013 & 4.2 & 15.4 & 585 & 220 \\
30 yr average & 2.6 & 14.2 & 541 & 199 \\
\hline
\end{tabular}

1072

1073 
1075 Table 3. Mean measured $\mathrm{CO}_{2}, \mathrm{CH}_{4}$ and $\mathrm{N}_{2} \mathrm{O}$ fluxes under different land use and warming

1076 treatments. $\mathrm{UD}=$ undrained, $\mathrm{R}=$ restored, $\mathrm{D}=$ drained, $\mathrm{A}=$ ambient $\mathrm{T}, \mathrm{O}=\mathrm{OTC}$ warming,

$1077 \mathrm{PG}=$ gross photosynthesis $\mathrm{Reco}=$ ecosystem respiration, and $\mathrm{NEE}=$ net $\mathrm{CO}_{2}$ exchange. Unit

1078 for gas fluxes is $\mathrm{mg} \mathrm{CO}_{2} / \mathrm{CH}_{4} / \mathrm{N}_{2} \mathrm{O} \mathrm{m}^{-2} \mathrm{~h}^{-1}$. The mean for PG and NEE is based only on light

1079 saturated measurements with PPFD $>800 \mu \mathrm{mol} \mathrm{m}^{-2} \mathrm{~s}^{-1}$.

\begin{tabular}{|c|c|c|c|c|c|c|c|}
\hline & & & $P G$ & & NEE & & \\
\hline Year & Land use & Warming & @PPFD>800 & Reco & @ $\mathrm{PPFD}>800$ & $\mathrm{CH}_{4}$ & $\mathrm{~N}_{2} \mathrm{O}$ \\
\hline \multirow[t]{12}{*}{ All } & UD1 & $\mathrm{A}$ & 955 & 396 & 496 & 0.2 & \\
\hline & & $\mathrm{O}$ & 1041 & 380 & 594 & 0.7 & \\
\hline & UD2 & A & 1115 & 414 & 605 & 0.7 & \\
\hline & & $\mathrm{O}$ & 935 & 374 & 490 & 1.1 & \\
\hline & R1 & A & 1116 & 409 & 517 & 1.1 & \\
\hline & & $\mathrm{O}$ & 1122 & 364 & 613 & 1.4 & \\
\hline & $\mathrm{R} 2$ & A & 959 & 374 & 446 & 0.6 & \\
\hline & & $\mathrm{O}$ & 919 & 335 & 469 & 0.6 & \\
\hline & D1 & A & 537 & 751 & -74 & 0.0 & \\
\hline & & $\mathrm{O}$ & 657 & 525 & 141 & 0.1 & \\
\hline & D2 & A & 796 & 337 & 349 & 0.4 & \\
\hline & & $\mathrm{O}$ & 830 & 363 & 365 & 0.4 & \\
\hline \multirow[t]{4}{*}{2011} & UD1 & $\mathrm{A}$ & 990 & 335 & 591 & 0.2 & 0.1 \\
\hline & & $\mathrm{O}$ & 1135 & 332 & 756 & 0.8 & 0.2 \\
\hline & UD2 & A & 983 & 313 & 609 & 0.6 & 0.2 \\
\hline & & $\mathrm{O}$ & 797 & 317 & 459 & 1.3 & 0.2 \\
\hline
\end{tabular}




\begin{tabular}{|c|c|c|c|c|c|c|c|}
\hline & $\mathrm{R} 1$ & A & 826 & 361 & 221 & 1.4 & 0.2 \\
\hline & & $\mathrm{O}$ & 873 & 327 & 417 & 1.8 & 0.3 \\
\hline & R2 & A & 994 & 363 & 522 & 0.8 & 0.2 \\
\hline & & $\mathrm{O}$ & 995 & 316 & 569 & 0.9 & 0.3 \\
\hline & D1 & A & 549 & 692 & -40 & 0.0 & 0.2 \\
\hline & & $\mathrm{O}$ & 679 & 473 & 166 & 0.1 & 0.2 \\
\hline & D2 & A & 711 & 316 & 307 & 0.5 & 0.3 \\
\hline & & $\mathrm{O}$ & 628 & 326 & 218 & 0.6 & 0.2 \\
\hline 2013 & UD1 & $\mathrm{A}$ & 934 & 427 & 440 & 0.2 & \\
\hline & & $\mathrm{O}$ & 983 & 406 & 496 & 0.6 & \\
\hline & UD2 & A & 1171 & 466 & 604 & 0.8 & \\
\hline & & $\mathrm{O}$ & 1017 & 414 & 509 & 0.8 & \\
\hline & R1 & A & 1228 & 438 & 631 & 0.2 & \\
\hline & & $\mathrm{O}$ & 1264 & 387 & 725 & 0.3 & \\
\hline & R2 & A & 921 & 382 & 363 & 0.4 & \\
\hline & & $\mathrm{O}$ & 839 & 349 & 364 & 0.2 & \\
\hline & D1 & A & 503 & 792 & -176 & 0.1 & \\
\hline & & $\mathrm{O}$ & 642 & 559 & 124 & 0.0 & \\
\hline & D2 & A & 852 & 352 & 377 & 0.1 & \\
\hline & & $\mathrm{O}$ & 980 & 390 & 474 & 0.0 & \\
\hline
\end{tabular}

1080

1081 
1082 Table 4. Global warming potential (GWP) of different land uses (UD = undrained, $\mathrm{R}=$

1083 restored, $\mathrm{D}=$ drained) based on gas fluxes calculated for growing seasons 2011 and 2013.

1084 GWP calculated based on 100-year time horizon (Myhre et al. 2013). The values are

1085 expressed as $\mathrm{g} \mathrm{CO}_{2 \text {-eq }} \mathrm{m}^{-2}$ season $^{-1}$ and positive values indicate net warming impact to

1086 atmosphere. The estimates for drained sites include the annual above-ground tree stand $\mathrm{CO}_{2}$

1087 sequestration, which would occur mostly during the growing season.

\begin{tabular}{ccc}
\hline Study site & GWP_2011 & GWP_2013 \\
\hline UD1 & 156 & 462 \\
UD2 & -114 & 145 \\
\hline R1 & 243 & 516 \\
R2 & -137 & 240 \\
\hline D1 & 178 & 334 \\
D2 & 709 & 971 \\
\hline
\end{tabular}

1088

1089 
1091

1092

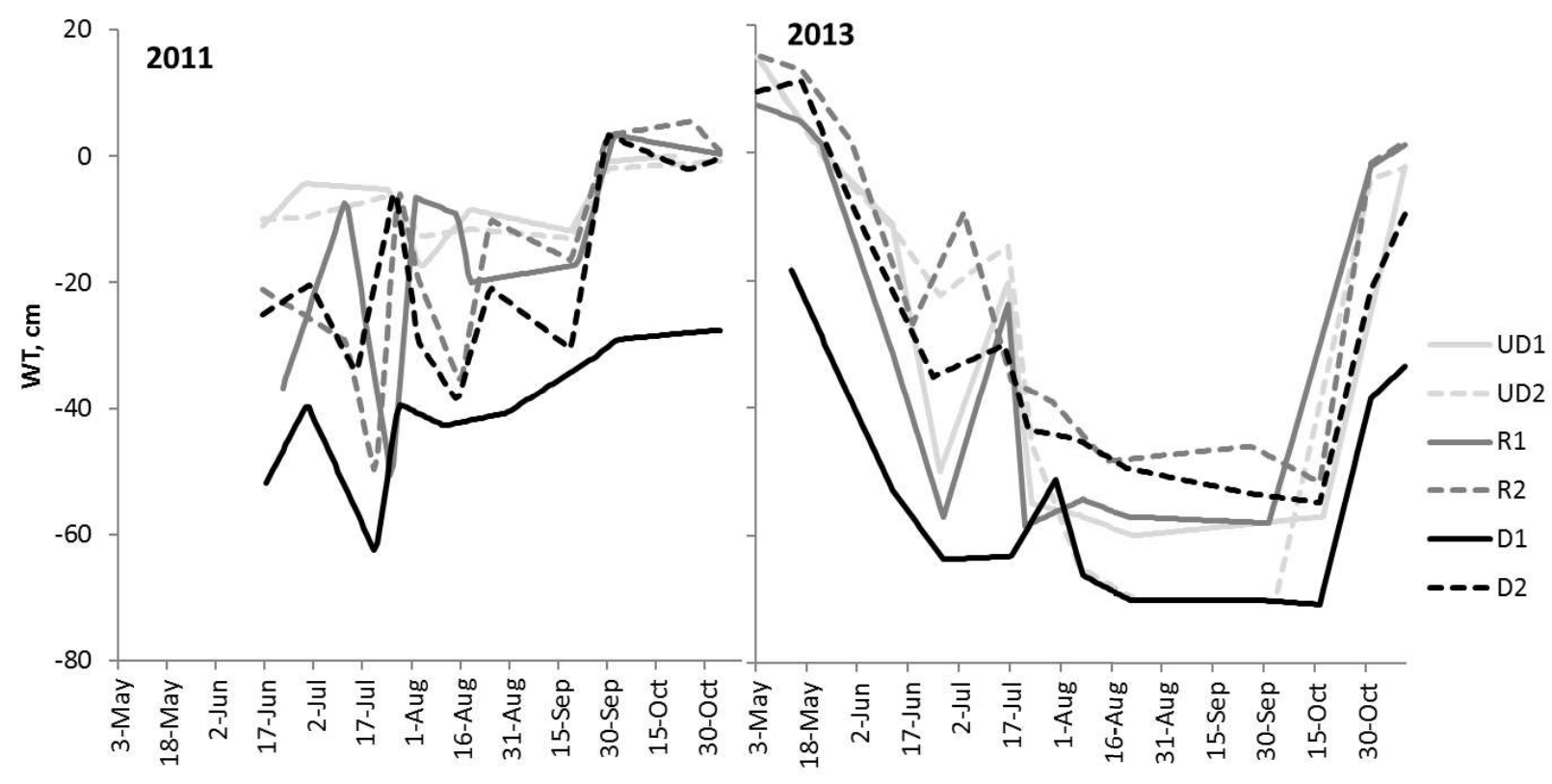

1093

1094 Figure 1. Water table (WT) in years 2011 and 2013 in the six study sites. UD = undrained, R $1095=$ restored and $\mathrm{D}=$ drained. Values below zero indicate WT below soil surface.

1096 

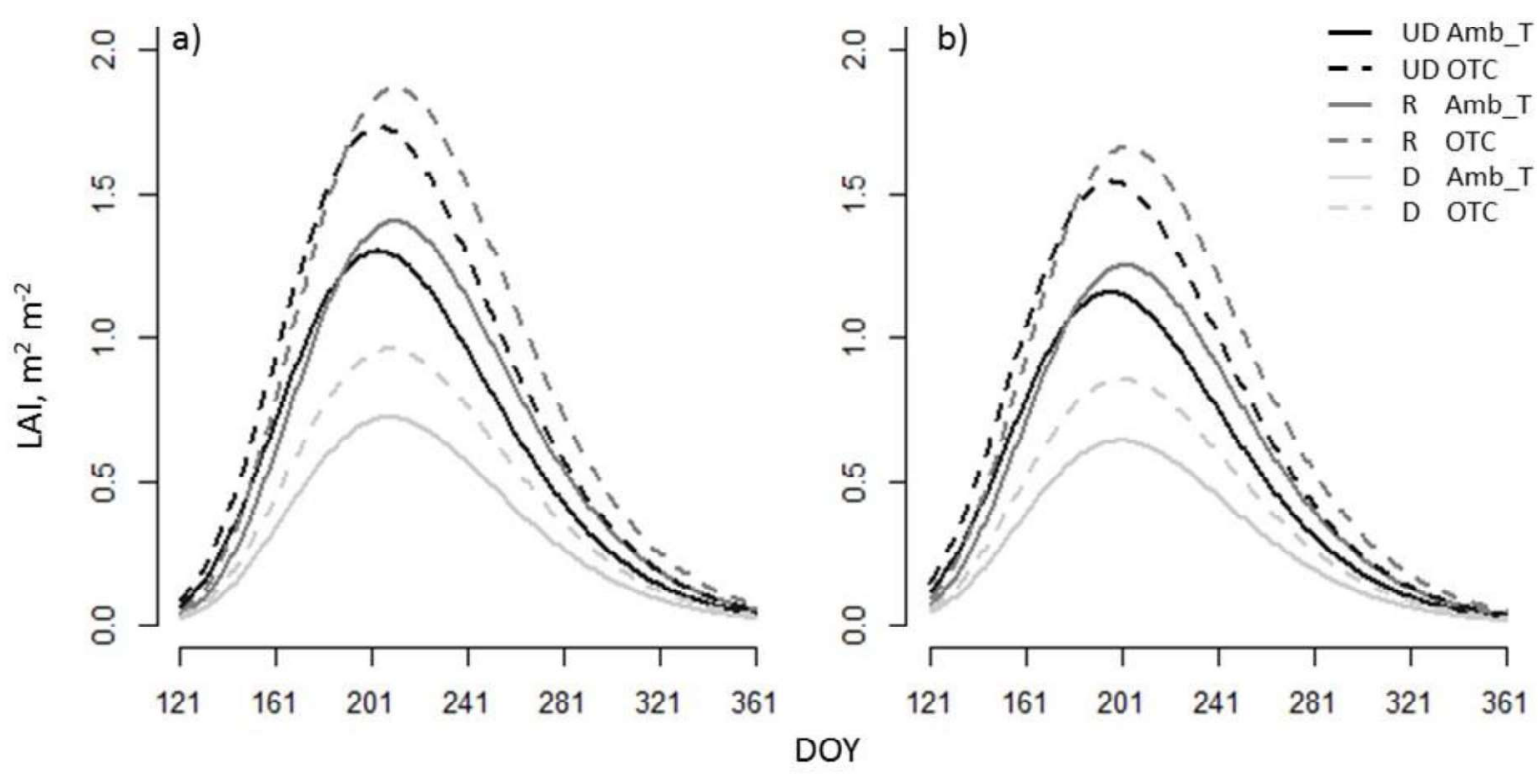

1098

1099 Figure 2. Seasonal development (May to December) of leaf area index (LAI) during a) year 11002011 and b) year 2013, in ambient-T (Amb_T, solid lines) and OTC warmed plots (dashed 1101 lines) at undrained (UD), restored (R) and drained (D) sites belonging to Group 1. As LAI of 1102 group 2 behaved at similar manner to group 1, those results are not shown here. 


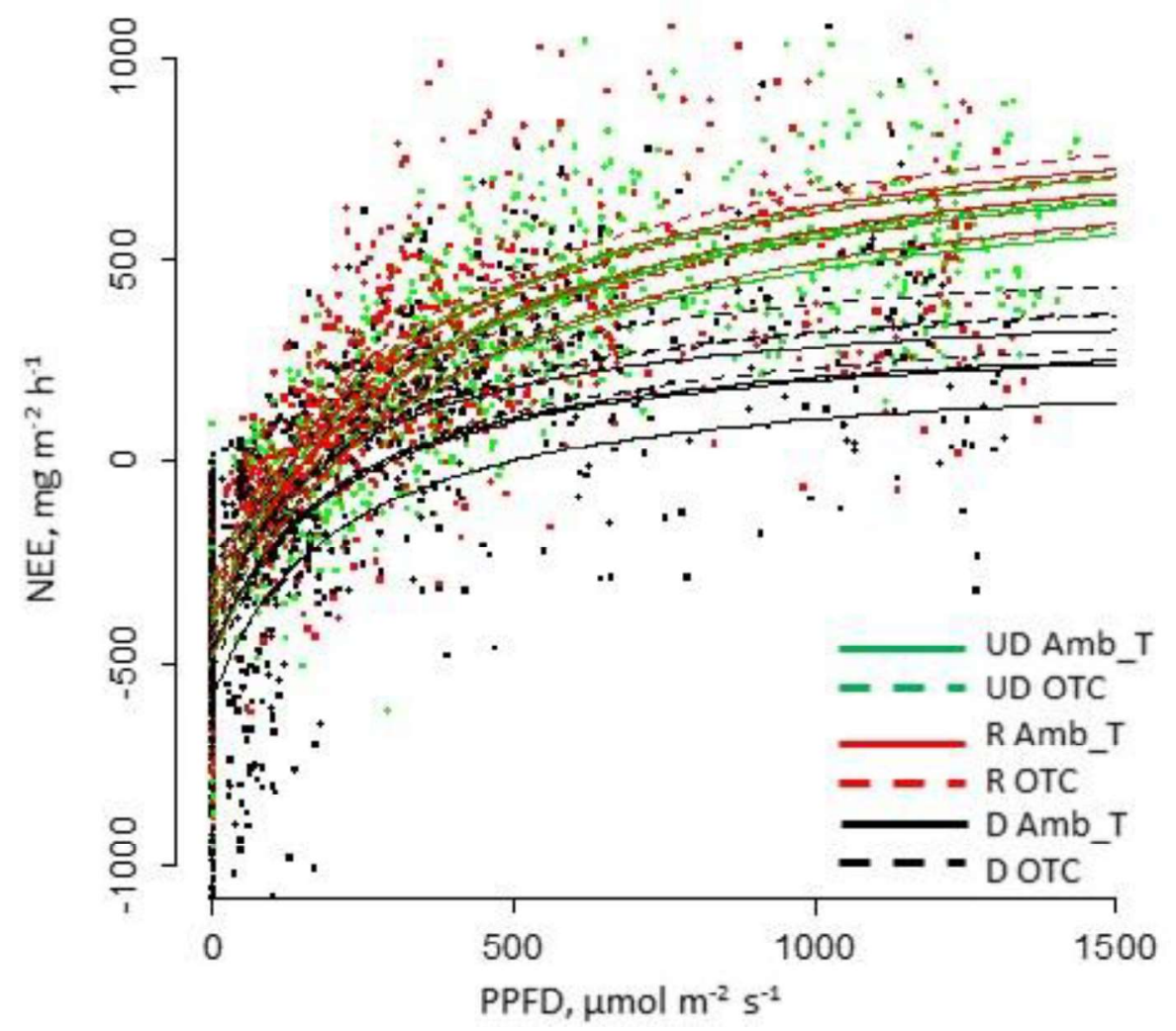

1106 Figure 3. Light response of net ecosystem $\mathrm{CO}_{2}$ exchange (NEE) under different land use and 1107 warming treatments. Scatter plot shows the measured fluxes, while the different response 1108 curves are based on $\mathrm{CO}_{2}$ model and represent the three land uses (UD $=$ undrained, $\mathrm{R}=$ 1109 restored, $\mathrm{D}=$ drained), warming treatments $\left(\mathrm{Amb} \_\mathrm{T}=\right.$ ambient-T, OTC $=$ OTC warming $)$, 1110 measurement years $(2011,2013)$ and site groups 1 and 2 . Therefore, the four lines per land 1111 use $\mathrm{x}$ warming treatment describe the variability caused by year and site group. 

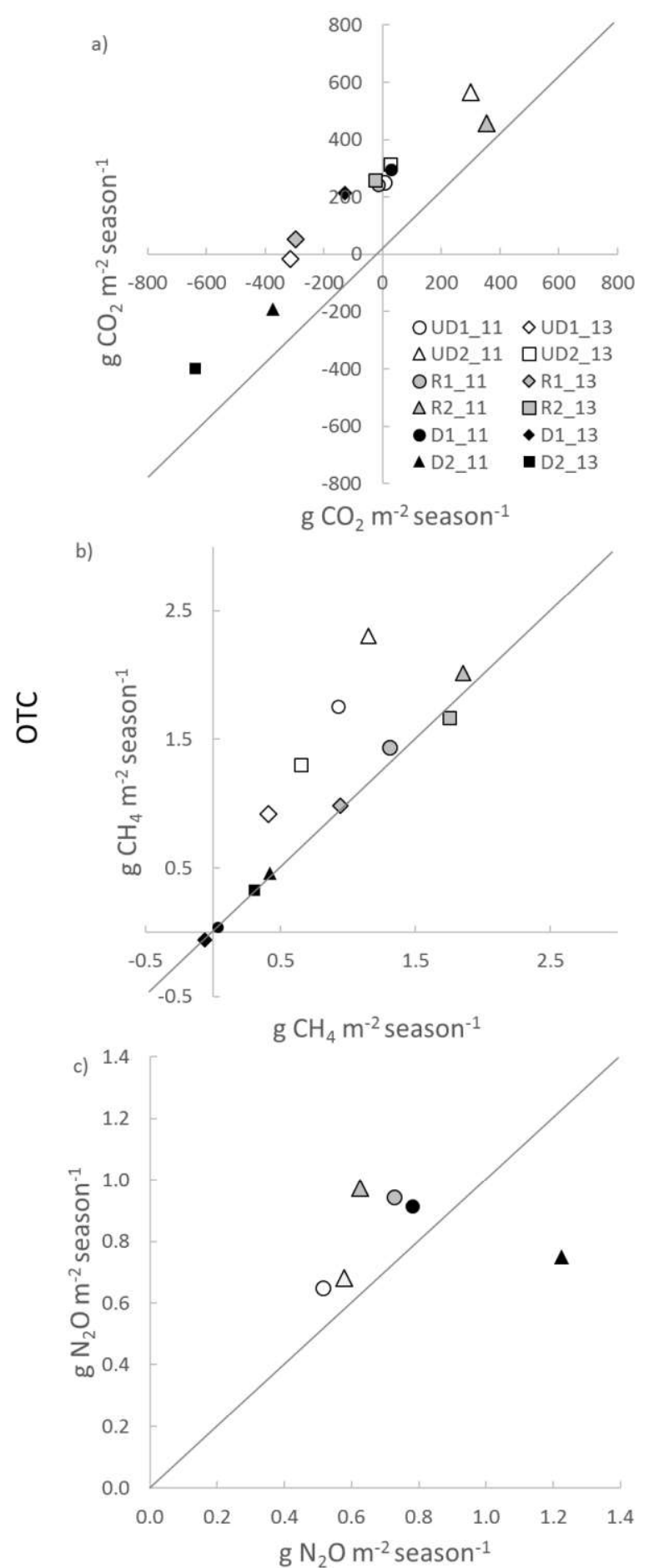

1114 Figure 4. Scatterplot of Ambient-T vs. OTC-warmed seasonal (May-September) cumulative 1115 flux of a) net ecosystem $\mathrm{CO}_{2}$ exchange (NEE), b) methane, c) nitrous oxide. Seasonal fluxes 1116 are calculated for OTC-warmed and ambient-T plots for each study site and for seasons 2011 1117 and 2013. UD: undrained, R: restored, D: drained. We added the annual average tree stand 1118 carbon sequestration of 959 and $423 \mathrm{~g} \mathrm{CO}_{2} \mathrm{~m}^{-2}$ to the field layer NEE estimates of sites D1 1119 and D2, respectively. 1:1 line is shown for each GHG component. 


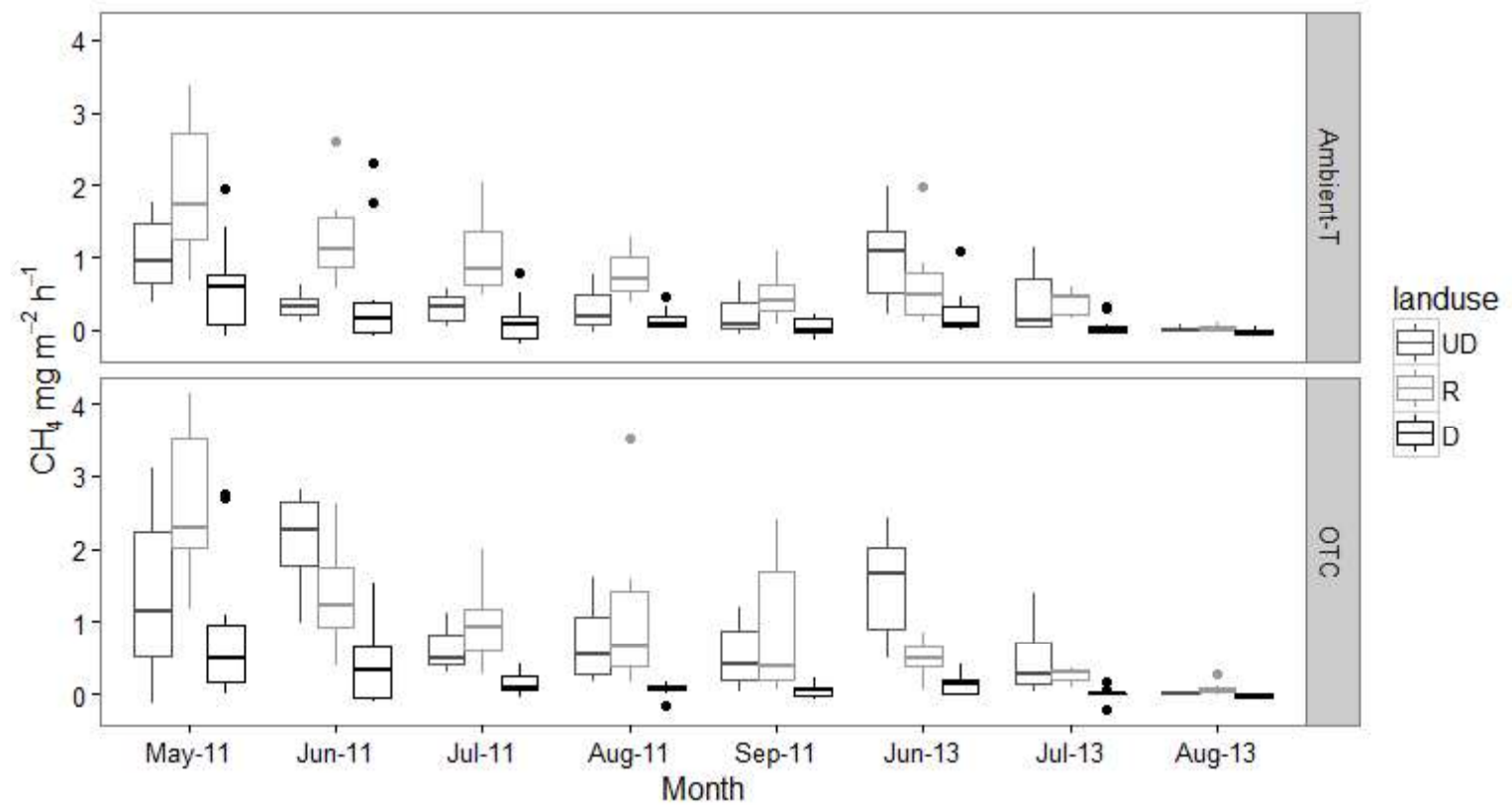

1122 Figure 5. Box-plot of average measured $\mathrm{CH}_{4}$ fluxes at undrained (UD), restored (R) and drained 1123 (D) sites under warmed (OTC) or ambient-T (C) temperature during the eight measurement 1124 campaigns at May, June, July, August and September of year 2011 and June, July and August 1125 of year 2013. Boxes represent range of middle two quartiles of the data, horizontal line is the 1126 median, and whiskers show the range excluding outliers (points). 

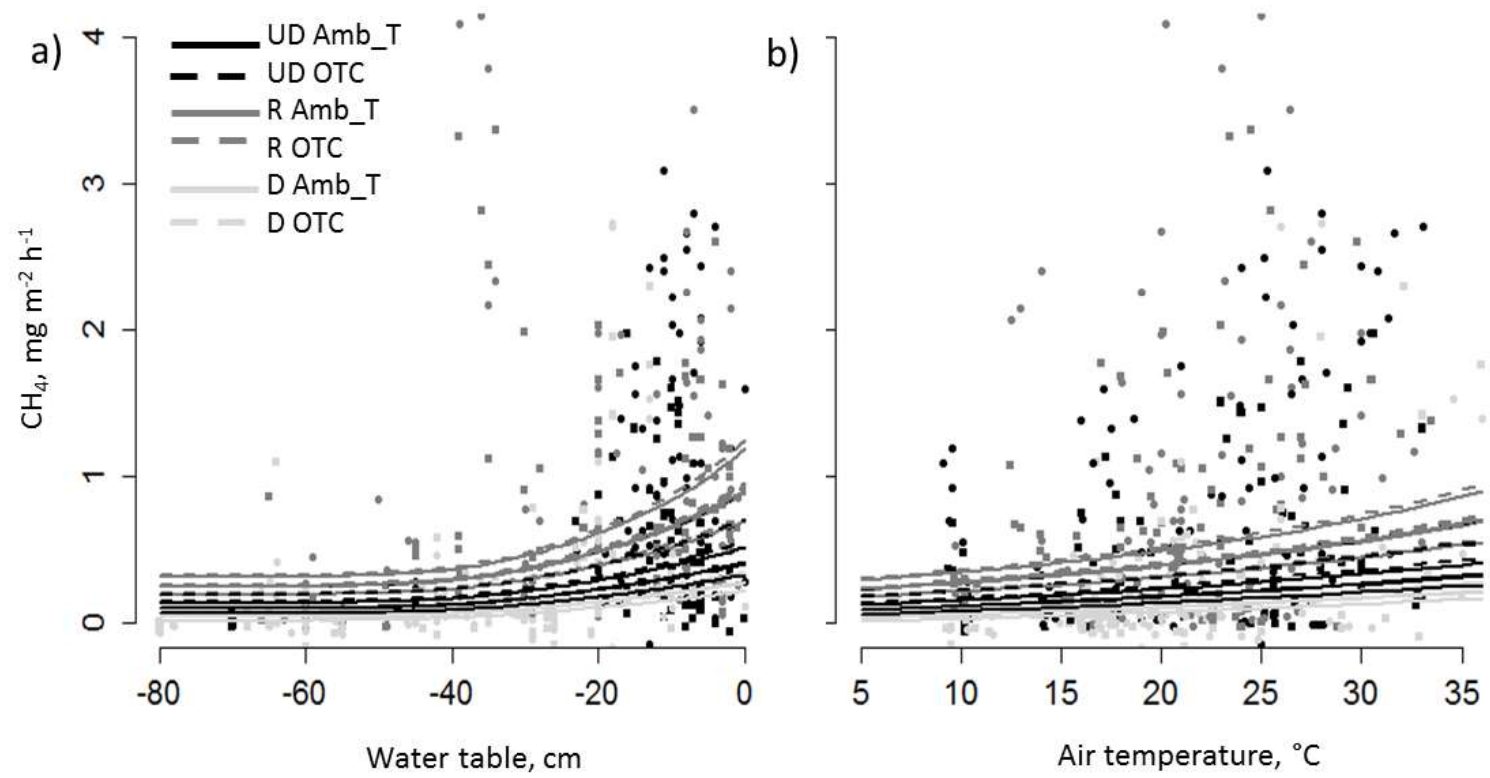

1129

1130 Figure 6. Scatter plot of measured fluxes and response curves from full $\mathrm{CH}_{4}$ model

1131 (Appendix 3). a) $\mathrm{CH}_{4}$ flux related to water table level and b) to air temperature.

1132 Environmental variables are standardized to following values based on data averages: WT: $113326.5 \mathrm{~cm}$, Ta: $20.79^{\circ} \mathrm{C}$, T5: $13.01^{\circ} \mathrm{C}$, field-layer LAI: $1.08 \mathrm{~m}^{2} \mathrm{~m}^{2}$.

1134

1135 


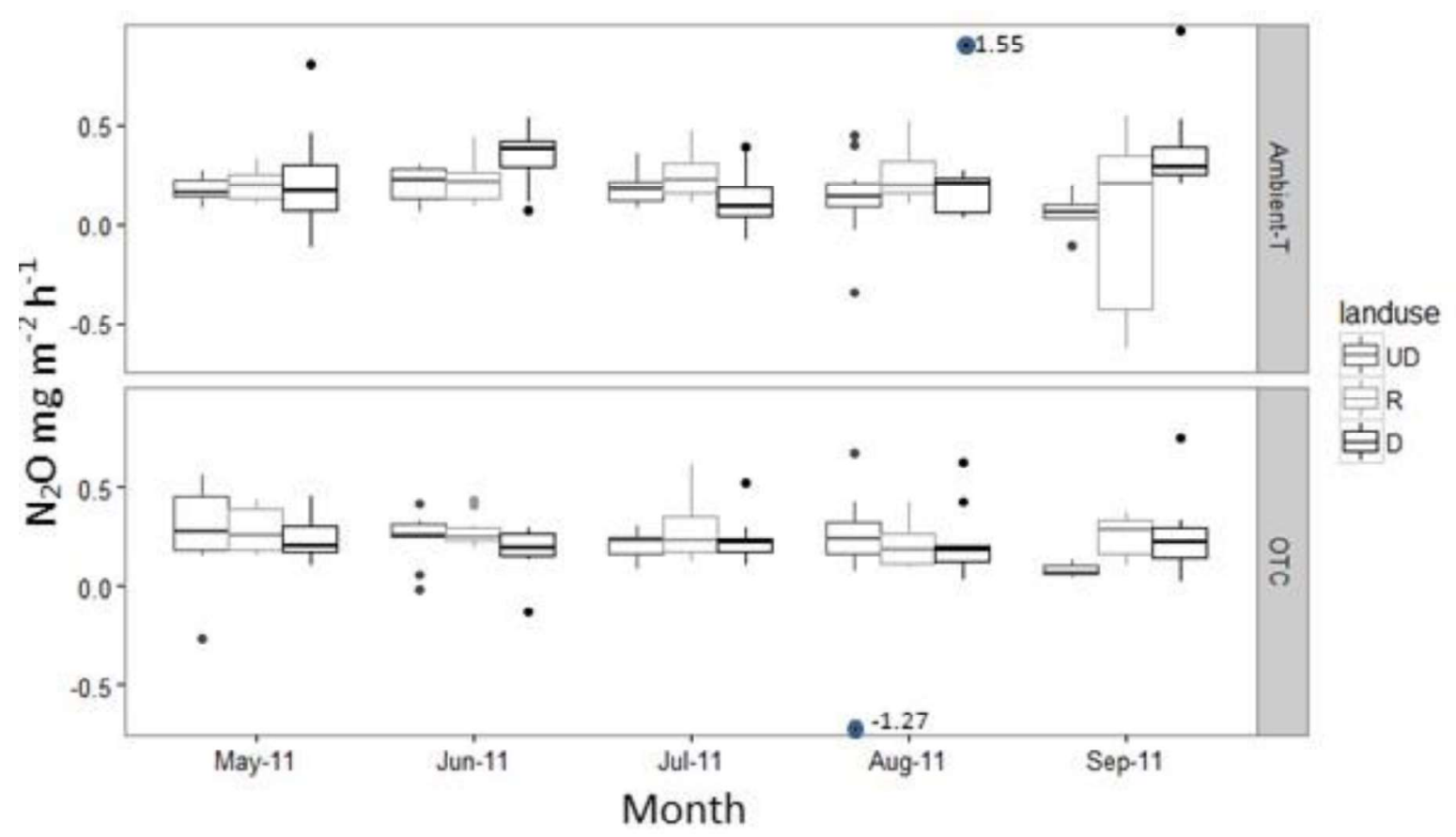

1138 Figure 7. Box-plot of $\mathrm{N}_{2} \mathrm{O}$ fluxes at undrained (UD), restored (R) and drained (D) sites under 1139 warmed (OTC) or ambient-T (C) temperature during the five measurement campaigns at

1140 May, June, July, August and September of year 2011. At the boxplot, the line that divides the 1141 box into two parts represents the median of the data and the end of the box shows the upper 1142 and lower quartiles. The whickers show the highest and lowest value excluding outliers, 1143 which are represented by points. The two extreme outliers are shown with respective values. 
1147 Supporting information for online publication

Nonlinear mixed-effect models

1148 for leaf area index and GHG fluxes

1149 Laine et al. Impacts of drainage, restoration and warming on boreal wetland greenhouse gas

1150 fluxes

$1151 \quad 0000-0003-2989-1591$

1152 Supporting information 1. Nonlinear mixed-effect model based on leaf area index

1153 Supporting information 2. Nonlinear mixed-effect model based on $\mathrm{CO}_{2}$ flux

1154 measurements

1155 Supporting information 3. Linear mixed effect models based on $\mathrm{CH}_{4}$ measurements

1156 Supporting information 4. Linear mixed effect models based on $\mathrm{N}_{2} \mathrm{O}$ measurements

1157 
1159 Table S1.1. ANOVA results of the non-linear mixed effects models (Eq. 1-3) for the

1160 differences in leaf area index (LAI) between land use (undrained, drained, restored), warming 1161 treatment, years (2011 and 2013) and group (two groups of sites: UD1, R1 and D1, and UD2, 1162 R2 and D2). LMAX is maximum LAI during growing season and DMAX is the day of year

1163 when maximum is reached.

1164

1165

\begin{tabular}{lllllrr}
\hline & & & LMAX & & DMAX \\
Source & numDF & denDF & F-value & p-value & F-value & p-value \\
\hline & & & & & & \\
Year & 1 & 648 & 8.12 & 0.005 & 19.93 & $<.0001$ \\
Land use & 2 & 648 & 6.7 & 0.001 & 5.08 & 0.006 \\
Warming & 1 & 648 & 8.64 & 0.003 & 0.06 & 0.803 \\
Group & 1 & 648 & 1.69 & 0.194 & 12.32 & 0.001 \\
\hline
\end{tabular}

1166 Table S1.2. Parameter estimates and random effects of nonlinear mixed-effects model of leaf 1167 area index (LAI) model (Eq.1-3). The bolded values are significant at $p<0.05$. Then drained 1168 site of group 1 with no warming in year 2011 is used as control.

\begin{tabular}{|c|c|c|c|c|c|c|c|}
\hline \multirow[b]{2}{*}{ Source } & \multicolumn{3}{|c|}{$\ln ($ LMAX) } & \multicolumn{2}{|l|}{$\ln (\mathrm{DMAX})$} & \multicolumn{2}{|l|}{$\ln (G)$} \\
\hline & $\mathrm{DF}$ & Value & Std.Error & Value & Std.Error & Value & $\begin{array}{l}\text { Std } \\
\text { Error }\end{array}$ \\
\hline \multicolumn{8}{|c|}{ Fixed part } \\
\hline Intercept & 648 & 0.26 & 0.17 & 5.32 & 0.01 & -1.52 & 0.121 \\
\hline Year 2013 & 648 & -0.12 & 0.04 & -0.04 & 0.01 & & \\
\hline Restoration & 648 & 0.08 & 0.20 & $\mathbf{0 . 0 3}$ & 0.01 & & \\
\hline Drainage & 648 & -0.59 & 0.20 & 0.02 & 0.01 & & \\
\hline Warming & 648 & 0.29 & 0.10 & 0.002 & 0.01 & & \\
\hline Group2 & 648 & 0.21 & 0.16 & -0.03 & 0.01 & & \\
\hline \multicolumn{8}{|c|}{ Random effects and residual } \\
\hline $\operatorname{var}\left(a_{i}\right)$ & & $0.16^{2}$ & & 0 & & $0.29^{2}$ & \\
\hline $\operatorname{var}\left(b_{i j}\right)$ & & $0.34^{2}$ & & $0.01^{2}$ & & 0 & \\
\hline $\operatorname{var}\left(c_{i j k}\right)$ & & $0.18^{2}$ & & $0.03^{2}$ & & $0.08^{2}$ & \\
\hline $\operatorname{var}\left(\varepsilon_{\mathrm{ijkl}}\right)$ & & $0.25^{2}$ & & & & & \\
\hline
\end{tabular}


1170 Supporting information 2. Nonlinear mixed-effect model based on $\mathrm{CO}_{2}$ flux

1171 measurements

1172 Table S2.1. ANOVA results of the simple non-linear mixed effects models, including only 1173 categorical treatments, based on $\mathrm{CO}_{2}$ measurements (Eq. 4-7).

\begin{tabular}{llcccc}
\hline & numDF & denDF & F-value & p-value \\
\hline $\ln ($ PMAX) & Intercept & & & & \\
& Year & 1 & 2241 & 0.03 & 0.854 \\
& Land use & 4 & 2241 & 13.46 & $<.0001$ \\
& Warming & 3 & 2241 & 0.72 & 0.538 \\
& Group & 1 & 2241 & 0.19 & 0.667 \\
& Land use :Warming & 2 & 2241 & 0.88 & 0.415 \\
\hline $\ln (\mathrm{R})$ & Intercept & & & & \\
& Year & 1 & 2241 & 42.75 & $<.0001$ \\
& Land use & 4 & 2241 & 0.99 & 0.409 \\
& Warming & 3 & 2241 & 1.39 & 0.244 \\
& Group & 1 & 2241 & 8.15 & 0.004 \\
& Land use :Warming & 2 & 2241 & 0.03 & 0.970 \\
\hline $\ln (\alpha)$ & Intercept & & & & \\
& Land use & 2 & 2241 & 13.85 & $<.0001$ \\
\hline
\end{tabular}

1174

1175 
1176 Table S2.2. Parameter estimates and random effects of the simple nonlinear mixed effect

1177 model, including only categorical treatments, based on $\mathrm{CO}_{2}$ measurements (Eq. 4-7). The 1178 undrained site of group 1 with no warming in year 2011 is used as control.

\begin{tabular}{|c|c|c|c|c|c|c|}
\hline Fixed part & & Value & Std.Error & DF & t-value & p-value \\
\hline \multirow[t]{8}{*}{$\ln (\mathrm{PMAX})$} & Intercept & 7.15 & 0.06 & & & \\
\hline & Year2013 & 0.01 & 0.03 & 2241 & 0.18 & 0.854 \\
\hline & Restored & 0.03 & 0.07 & 2241 & 0.42 & 0.671 \\
\hline & Drained & -0.43 & 0.08 & 2241 & -5.68 & $<.0001$ \\
\hline & Warming & -0.02 & 0.06 & 2241 & -0.36 & 0.717 \\
\hline & Group2 & -0.02 & 0.04 & 2241 & -0.43 & 0.667 \\
\hline & Restored : Warming & 0.03 & 0.08 & 2241 & 0.36 & 0.721 \\
\hline & Drained : Warming & 0.11 & 0.09 & 2241 & 1.29 & 0.199 \\
\hline \multirow[t]{8}{*}{$\ln (\mathrm{R})$} & Intercept & 6.00 & 0.10 & & & \\
\hline & Year2013 & 0.19 & 0.03 & 2241 & 6.54 & $<.0001$ \\
\hline & Restored & -0.02 & 0.12 & 2241 & -0.20 & 0.845 \\
\hline & Drained & 0.18 & 0.12 & 2241 & 1.47 & 0.142 \\
\hline & Warming & -0.08 & 0.09 & 2241 & -0.96 & 0.336 \\
\hline & Group2 & -0.22 & 0.08 & 2241 & -2.85 & 0.004 \\
\hline & Restored : Warming & -0.02 & 0.12 & 2241 & -0.13 & 0.899 \\
\hline & Drained : Warming & -0.03 & 0.12 & 2241 & -0.25 & 0.804 \\
\hline \multirow[t]{3}{*}{$\ln (\alpha)$} & Intercept) & 5.82 & 0.07 & & & \\
\hline & Restored & 0.08 & 0.10 & 2241 & 0.81 & 0.420 \\
\hline & Drained & -0.48 & 0.11 & 2241 & -4.30 & $<.0001$ \\
\hline Random part & & PMAX & $\mathrm{R}$ & $\alpha$ & & \\
\hline $\operatorname{var}\left(a_{i}\right)$ & & $0.00^{2}$ & $0.09^{2}$ & $0.06^{2}$ & & \\
\hline $\operatorname{var}\left(b_{i j}\right)$ & & $0.00^{2}$ & $0.16^{2}$ & $0.00^{2}$ & & \\
\hline $\operatorname{var}\left(c_{i j k}\right)$ & & $0.19^{2}$ & $0.11^{2}$ & $5.42^{2}$ & & \\
\hline $\operatorname{var}\left(\mathrm{d}_{\mathrm{ijkl}}\right)$ & & $0.25^{2}$ & $0.37^{2}$ & 0 & & \\
\hline $\operatorname{corr}\left(\mathrm{d}_{\mathrm{ijkl}} \wedge \mathrm{P}, \mathrm{d}_{\mathrm{ijkl}}\right)$ & & 1 & & & & \\
\hline $\operatorname{var}\left(\varepsilon_{\mathrm{ijklm}}\right)$ & & $100.25^{2}$ & & & & \\
\hline
\end{tabular}

1179

1180

1181 
1182 Table S2.3. ANOVA results of the full nonlinear mixed effect model, including

1183 environmental variables, based on $\mathrm{CO}_{2}$ measurements (Eq. 4-7). Ta= air temperature, a1 = 1184 spline component based on a three-knot spline, LAI2 $=$ is the plot level modelled leaf area

1185 (Eq 1-3) transformed as $\ln (1-\exp (-\mathrm{LAI})), \min (\mathrm{t} 15,10)=$ soil temperature at $15 \mathrm{~cm}$ depth, $1186 \log (\mathrm{LAI})=$ is logarithmically transformed LAI.

\begin{tabular}{llcccc}
\hline & & numDF & denDF & F-value & p-value \\
\hline $\ln ($ PMAX) & & & & & \\
& Year & 1 & 2235 & 19.77 & $<.0001$ \\
& Land use & 4 & 2235 & 1.63 & 0.163 \\
& Warming & 3 & 2235 & 1.08 & 0.355 \\
& Group & 1 & 2235 & 5.58 & 0.018 \\
& Ta/a1 & 2 & 2235 & 19.87 & $<.0001$ \\
& & & & \\
& LAI2 & 1 & 2235 & 219.32 & $<.0001$ \\
& Land use :Warming & 2 & 2235 & 0.40 & 0.669 \\
\hline $\ln (\mathrm{R})$ & & & & \\
& Year & 1 & 2235 & 188.08 & $<.0001$ \\
& Land use & 4 & 2235 & 1.31 & 0.262 \\
& Warming & 3 & 2235 & 4.42 & 0.004 \\
& Group & 1 & 2235 & 3.88 & 0.048 \\
& Ta & 1 & 2235 & 365.16 & $<.0001$ \\
& Log(LAI) & & & & \\
& min(T15, 10) & 1 & 2235 & 95.89 & $<.0001$ \\
& Land use : Warming & 2 & 2235 & 220.53 & $<.0001$ \\
& Land use & & 0.40 & 0.670 \\
\hline $\ln (\alpha)$ & 2 & 2235 & 7.72 & 0.001 \\
\hline
\end{tabular}

1187

1188 
1189 Table S2.4. Parameter estimates and random effects of the full nonlinear mixed effect model, 1190 including environmental variables, based on $\mathrm{CO}_{2}$ measurements (Eq. 4-7). The undrained site 1191 of group 1 with no warming in year 2011 is used as the control.

\begin{tabular}{|c|c|c|c|c|c|c|}
\hline Fixed part & & Value & Std.Error & DF & t-value & p-value \\
\hline \multirow[t]{11}{*}{$\ln (\mathrm{PMAX})$} & Intercept & 6.88 & 0.13 & & & \\
\hline & Year2013 & 0.15 & 0.03 & 2235 & 4.45 & $<.0001$ \\
\hline & Restored & -0.01 & 0.11 & 2235 & -0.05 & 0.961 \\
\hline & Drained & -0.16 & 0.11 & 2235 & -1.43 & 0.152 \\
\hline & Warming & -0.08 & 0.08 & 2235 & -0.95 & 0.343 \\
\hline & Group2 & -0.15 & 0.06 & 2235 & -2.36 & 0.018 \\
\hline & $\mathrm{Ta}$ & 0.03 & 0.01 & 2235 & 6.29 & $<.0001$ \\
\hline & a1 & 0.00 & 0.00 & 2235 & -5.68 & $<.0001$ \\
\hline & LAI2 & 0.65 & 0.04 & 2235 & 14.81 & $<.0001$ \\
\hline & Restored :Warming & 0.05 & 0.11 & 2235 & 0.47 & 0.641 \\
\hline & Drained : Warming & -0.05 & 0.12 & 2235 & -0.44 & 0.663 \\
\hline \multirow[t]{11}{*}{$\ln (\mathrm{R})$} & Intercept & 4.02 & 0.18 & & & \\
\hline & Year2013 & 0.28 & 0.02 & 2235 & 13.71 & $<.0001$ \\
\hline & Restored & -0.06 & 0.22 & 2235 & -0.27 & 0.789 \\
\hline & Drained & 0.39 & 0.22 & 2235 & 1.82 & 0.069 \\
\hline & Warming & -0.14 & 0.09 & 2235 & -1.61 & 0.106 \\
\hline & Group2 & -0.17 & 0.09 & 2235 & -1.97 & 0.049 \\
\hline & $\mathrm{Ta}$ & 0.03 & 0.00 & 2235 & 19.11 & $<.0001$ \\
\hline & $\log (\mathrm{LAI})$ & 0.24 & 0.02 & 2235 & 9.79 & $<.0001$ \\
\hline & $\operatorname{Pmin}(T 15,10)$ & 0.14 & 0.01 & 2235 & 14.85 & $<.0001$ \\
\hline & Restored: Warming & -0.01 & 0.12 & 2235 & -0.08 & 0.935 \\
\hline & Drained: Warming & -0.10 & 0.12 & 2235 & -0.81 & 0.418 \\
\hline \multirow[t]{3}{*}{$\ln (\alpha)$} & Intercept & 5.65 & 0.09 & & & \\
\hline & Restored & 0.14 & 0.13 & 2235 & 1.14 & 0.254 \\
\hline & Drained & -0.38 & 0.13 & 2235 & -2.80 & 0.005 \\
\hline Random part & & PMAX & $\mathrm{R}$ & $\alpha$ & & \\
\hline $\operatorname{var}\left(a_{i}\right)$ & & $0.06^{2}$ & $0.20^{2}$ & $0.1^{2}$ & & \\
\hline $\operatorname{var}\left(b_{i j}\right)$ & & $0.13^{2}$ & $0.18^{2}$ & $0.00^{2}$ & & \\
\hline $\operatorname{var}\left(c_{i j k}\right)$ & & $0.17^{2}$ & $0.04^{2}$ & $0.25^{2}$ & & \\
\hline $\operatorname{var}\left(\mathrm{d}_{\mathrm{ijkl}}\right)$ & & $0.23^{2}$ & $0.19^{2}$ & & & \\
\hline $\operatorname{corr}\left(\mathrm{d}_{\mathrm{ijk}} \wedge^{\wedge} \mathrm{P}, \mathrm{d}_{\mathrm{ijk} \mathrm{l}}\right)$ & & & $0.58^{2}$ & & & \\
\hline $\operatorname{var}\left(\varepsilon_{\mathrm{ijklm}}\right)$ & & & 78.41 & & & \\
\hline
\end{tabular}


1194 Supporting information 3. Linear mixed effect models based on $\mathrm{CH}_{4}$ measurements

1195 Table S3.1. ANOVA results of the simple linear mixed effect model, including categorical

1196 treatments, based on $\mathrm{CH}_{4}$ measurements, using the transformation $-1 /\left(\mathrm{CH}_{4}+0.4\right)$.

\begin{tabular}{lcccccc}
\hline & Sum & mean & & & & \\
& Sq & Sq & NumDF & DenDF & F.value & $\operatorname{Pr}(>$ F $)$ \\
\hline Year & 0.66 & 0.66 & 1 & 6.02 & 2.43 & 0.170 \\
Land use & 2.29 & 1.14 & 4 & 2.48 & 3.78 & 0.182 \\
Warming & 1.15 & 1.15 & 3 & 51.86 & 3.65 & 0.018 \\
Group & 0.27 & 0.27 & 1 & 0.00 & 0.98 & \\
Land use:Warming & 1.86 & 0.93 & 2 & 51.84 & 3.39 & 0.041 \\
\hline
\end{tabular}

1197

1198 Table S3.2. Parameter estimates and random effects of the simple linear mixed effect model, 1199 including categorical treatments, based on $\mathrm{CH}_{4}$ measurements. Measurements from the 1200 undrained site of group 1 with no warming in year 2011 are used as the control.

\begin{tabular}{lccccc}
\hline Fixed part & Estimate & Std.Error & $\mathrm{df}$ & $\mathrm{t}$ & $\mathrm{p}$ value \\
\hline Intercept & -1.49 & 0.36 & & & \\
Year 2013 & -0.50 & 0.32 & 6.0 & -1.56 & 0.170 \\
Restored & 0.40 & 0.38 & 2.2 & 1.06 & 0.395 \\
Drained & -0.61 & 0.38 & 2.2 & -1.62 & 0.237 \\
Warming & 0.35 & 0.11 & 51.7 & 3.30 & 0.002 \\
Group2 & 0.30 & 0.30 & 2.0 & 0.99 & 0.427 \\
Restored : Warming & -0.33 & 0.15 & 52.7 & -2.18 & 0.034 \\
Drained : Warming & -0.35 & 0.15 & 50.9 & -2.32 & 0.024 \\
\hline Random part & Variance & & & & \\
site & $0.36^{2}$ & & & & \\
plot:site & $0.15^{2}$ & & & & \\
mestime & $0.43^{2}$ & & & & \\
Residual & $0.52^{2}$ & & & & \\
\hline
\end{tabular}

1201

1202 
1203 Table S3.3. ANOVA results of the full linear mixed effect model, including environmental 1204 variables, for $\mathrm{CH}_{4}$ measurements $\left(-1 / \mathrm{CH}_{4}+0.4\right)$. LAI_S $=$ is the modelled plot level leaf area 1205 including only sedges $(\mathrm{Eq} 1-3), \mathrm{WT}=$ water table, $\mathrm{a} 1=$ the second term of the three-knot 1206 spline for $\mathrm{WT}, \mathrm{Ta}=$ air temperature, $\mathrm{T} 5=$ soil temperature in $5 \mathrm{~cm}$ depth.

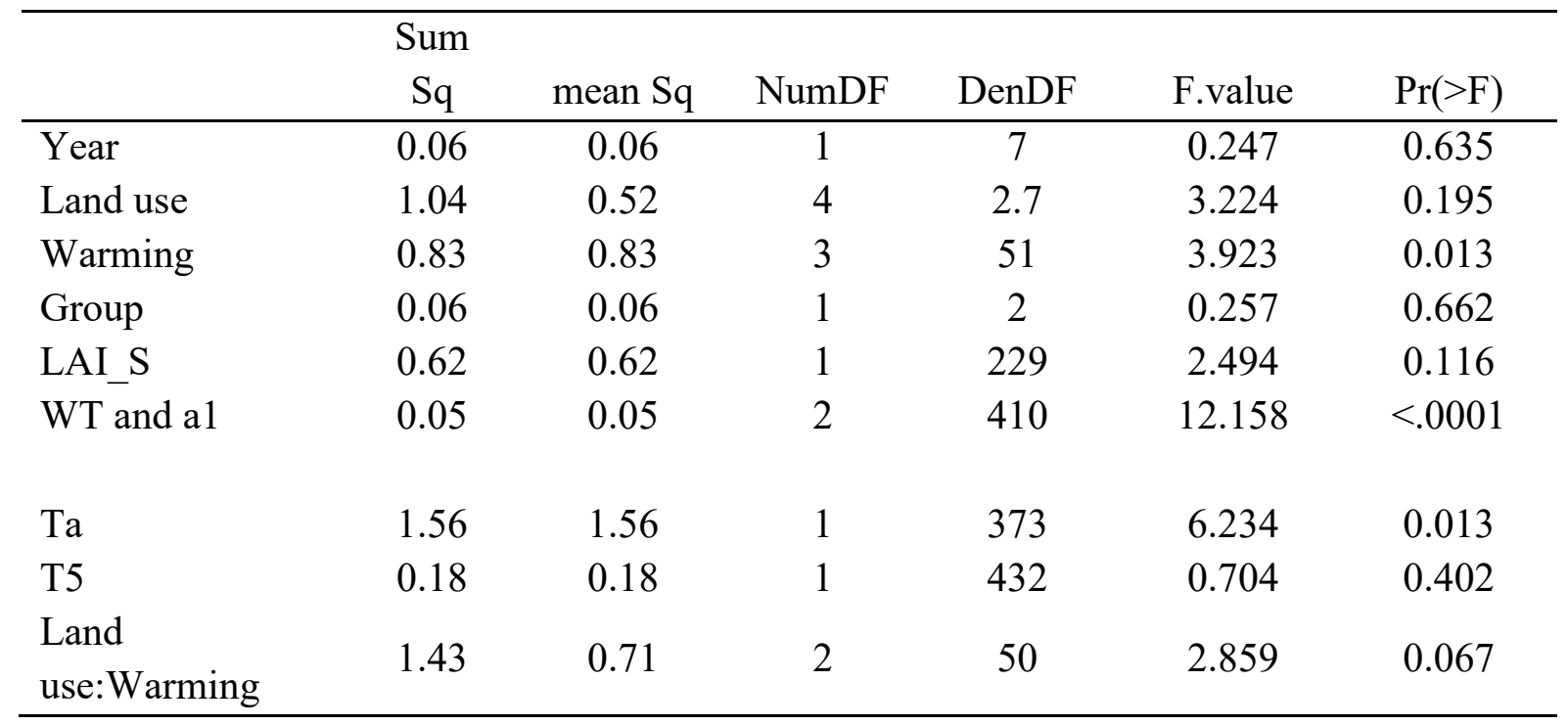

1207

1208 Table S3.4. Parameter estimates and random effects of the full linear mixed effect model 1209 including environmental variables, based on $\mathrm{CH}_{4}$ measurements. Measurements from 1210 undrained site of group 1 with no warming in year 2011 are used as the control.

\begin{tabular}{lccccc}
\hline Fixed part & Estimate & Std.Error & $\mathrm{df}$ & $\mathrm{t}$ & $\mathrm{p}$ value \\
\hline Intercept & -2.55 & 0.54 & & & \\
Year2013 & -0.13 & 0.27 & 7 & -0.50 & 0.635 \\
Restored & 0.46 & 0.36 & 2 & 1.28 & 0.320 \\
Drained & -0.25 & 0.36 & 2 & -0.68 & 0.558 \\
Warming & 0.32 & 0.11 & 52 & 2.97 & 0.005 \\
Group2 & 0.15 & 0.29 & 2 & 0.51 & 0.662 \\
LAI_S & 0.11 & 0.07 & 230 & 1.58 & 0.116 \\
WT & 0.00 & 0.01 & 404 & 0.45 & 0.653 \\
a1 & 0.00 & 0.00 & 416 & 1.83 & 0.069 \\
Ta & 0.02 & 0.01 & 373 & 2.50 & 0.013 \\
T5 & 0.02 & 0.02 & 432 & 0.84 & 0.402 \\
Restored: Warming & -0.30 & 0.15 & 52 & -1.95 & 0.057 \\
Drained: Warming & -0.33 & 0.15 & 49 & -2.18 & 0.034 \\
\hline Random part & Variance &. & & & \\
\hline site & $0.34^{2}$ & & & & \\
plot:site & $0.16^{2}$ & & & & \\
mestime & $0.34^{2}$ & & & & \\
Residual & $0.50^{2}$ & & & & \\
\hline
\end{tabular}


1211 Supporting information 4. Linear mixed effect models based on $\mathbf{N}_{2} \mathrm{O}$ measurements

1212 Table AS.1. ANOVA results of the simple linear mixed effect model, including only

1213 categorical treatments, for $\mathrm{N}_{2} \mathrm{O}$ measurements.

\begin{tabular}{lcccccc}
\hline & Sum & & & & & \\
& Sq & mean Sq & NumDF & DenDF & F.value & $\operatorname{Pr}(>\mathrm{F})$ \\
\hline Land use & 0.17 & 0.09 & 4 & 284.12 & 2.74 & 0.029 \\
Warming & 0.11 & 0.11 & 3 & 284.12 & 2.96 & 0.033 \\
group & 0.02 & 0.02 & 1 & 284.33 & 0.56 & 0.455 \\
Land use:Warming & 0.14 & 0.07 & 2 & 284.14 & 2.46 & 0.087 \\
\hline
\end{tabular}

1214

1215 Table S4.2. Parameter estimates and random effects of the simple linear mixed effect model, 1216 including only categorical treatments, based on $\mathrm{N}_{2} \mathrm{O}$ measurements. Measurements from 1217 undrained site of group 1 with no warming in year 2011 are used as the control.

\begin{tabular}{lccccc}
\hline Fixed part & Estimate & Std.Error & $\mathrm{df}$ & $\mathrm{t}$ & $\mathrm{p}$ value \\
\hline Intercept & 0.14 & 0.03 & & & \\
Restored & 0.04 & 0.03 & 284.11 & 1.03 & 0.302 \\
Drained & 0.10 & 0.03 & 284.19 & 2.90 & 0.004 \\
Warming & 0.06 & 0.03 & 284.11 & 1.80 & 0.073 \\
group2 & 0.01 & 0.02 & 284.33 & 0.75 & 0.455 \\
Restored :Warming & 0.02 & 0.05 & 284.08 & 0.32 & 0.751 \\
Drained :Warming & -0.08 & 0.05 & 284.21 & -1.74 & 0.084 \\
\hline Random part & Variance & & & & \\
\hline site & 0 & & & & \\
plot:site & 0 & & & & \\
meastime & $0.02^{2}$ & & & & \\
Residual & $0.17^{2}$ & & & & \\
\hline
\end{tabular}

1218

1219 
1220 Table S4.3. ANOVA results of the full linear mixed effect model including also

1221 environmental variables for $\log$ transformed $\mathrm{N}_{2} \mathrm{O}$ measurements. $\mathrm{WT}=$ water table, $\mathrm{Ta}=$ air 1222 temperature and LAI $=$ is the modelled plot level leaf area (Eq 1-3),

\begin{tabular}{lcccccc}
\hline & Sum Sq & mean Sq & NumDF & DenDF & F.value & $\operatorname{Pr}(>\mathrm{F})$ \\
\hline Land use & 0.100 & 0.050 & 4 & 285 & 2.07 & 0.084 \\
Warming & 0.086 & 0.086 & 3 & 285 & 2.53 & 0.058 \\
Group & 0.020 & 0.020 & 1 & 285 & 0.68 & 0.409 \\
WT & 0.012 & 0.012 & 1 & 285 & 0.41 & 0.525 \\
Ta & 0.052 & 0.052 & 1 & 285 & 1.82 & 0.178 \\
LAI & 0.017 & 0.017 & 1 & 285 & 0.61 & 0.437 \\
\hline
\end{tabular}

1223

1224 Table S4.4. Parameter estimates and random effects of the full linear mixed effect model 1225 including environmental variables, based on $\log$ transformed $\mathrm{N}_{2} \mathrm{O}$ measurements.

1226 Measurements from undrained site of group 1 with no warming in year 2011 are used as the 1227 control.

\begin{tabular}{lccccc}
\hline Fixed part & Estimate & Std.Error & $\mathrm{df}$ & $\mathrm{t}$ & $\mathrm{p}$ value \\
\hline Intercept & 0.085 & 0.040 & & & \\
Restored & 0.033 & 0.034 & 285 & 0.97 & 0.333 \\
Drained & 0.094 & 0.040 & 285 & 2.33 & 0.020 \\
Warming & 0.061 & 0.035 & 285 & 1.73 & 0.084 \\
Group2 & 0.018 & 0.021 & 285 & 0.83 & 0.409 \\
WT & -0.001 & 0.001 & 285 & -0.64 & 0.525 \\
Ta & 0.002 & 0.001 & 285 & 1.35 & 0.178 \\
LAI & 0.012 & 0.015 & 285 & 0.78 & 0.437 \\
Restored :Warming & 0.011 & 0.048 & 285 & 0.22 & 0.828 \\
Drained :Warming & -0.085 & 0.049 & 285 & -1.76 & 0.080 \\
\hline Random part & Variance & & & & \\
\hline site & $1.74 \mathrm{E}-08^{2}$ & & & & \\
plot:site & $0.00 \mathrm{E}+00^{2}$ & & & & \\
meastime & $0.00 \mathrm{E}+00^{2}$ & & & & \\
Residual & $1.69 \mathrm{E}-01^{2}$ & & & &
\end{tabular}

